\title{
Chemically Deposited CulnSe 2 Thin Films and their Photovoltaic Properties: A Review
}

\author{
Balasaheb M. Palve, ${ }^{1}$ Chaitali V. Jagtap, ${ }^{1}$ Vishal S. Kadam, ${ }^{1}$ Chandrakant D. Lokhande ${ }^{2}$ and Habib M. Pathan ${ }^{1, *}$
}

\begin{abstract}
Copper Indium di-Selenium, $\mathrm{CuInSe}_{2}$ (CISe), is the most promising absorber material for thin-film solar cells. ClSe based solar cells have shown long-term stability and the highest conversion efficiency of all thin-film solar cells, above $19 \%$. Moreover, CISe based solar cells are very stable and thus their operational lifetimes are long. The deposition method generally has a large impact on the resulting film properties as well as on the production costs. CISe can be prepared by a variety of methods like physical and chemical methods. The present review discusses first the liquid phase synthesis method like chemical bath deposition (CBD), electro-deposition (ED), spray pyrolysis (SP), and successive ionic layer adsorption and reaction method (SILAR), etc. Next, the structural, optical, electrical, and photo-electrochemical properties of CISe, as well as the features of solar cells made thereof are reviewed. The last part of the text deals with the application of CISe thin-film absorbers in solar cells. The photo-response properties of the ClSe are discussed how they can improve the efficiency and reduce the cost in potential applications.
\end{abstract}

Keywords: CISe; Solar cell; Thin film; Chemical method; Photo-electrochemical.

Received: 10 August 2020; Accepted: 21 September 2020.

Article type: Review article.

\section{Introduction}

Due to rising energy demands, depletion of fossil fuel, and environmental pollution, researchers are searchingthe new era for energy conversion devices, which give high efficiency. One alternative for this purpose is photovoltaic (solar energy converted into electrical energy). Solar cell devices are easy to be installed and used and have prolonged operational lifetimes, which avoid the need for continuous maintenance. One of the main difficulties for solar cell devices is that the price of the electricity (cost per watt) produced by solar cell devices is not yet reasonable. The problem related to the cost can be reduced by either using a high-efficiency device or minimizing the production costs of solar cell modules. The production costs will be minimized with increasing the production volume. To solve this problem, researcher is finding some low-cost alternative materials, which are useful for photovoltaic.

Nowadays, the most promising absorber materials for solar cells are CISe-based chalcopyrite materials. The properties of materials can be varied by doping some material like indium

\footnotetext{
${ }^{I}$ Advanced Physics Laboratory, Department of Physics, Savitribai

Phule Pune University Pune - 411007, Maharashtra India

${ }^{2}$ D. Y. Patil University, Kolhapur-416006, Maharashtra, India.

*E-mail: pathan@physics.unipune.ac.in (H.M. Pathan)
}

by gallium or of selenium by sulfur to form $\mathrm{Cu}(\mathrm{In}, \mathrm{Ga})(\mathrm{S}, \mathrm{Se})_{2}$. The efficiencies by using this material have been achieved higher than $19 \%$. CISe is a member of the I-III-VI2 group of semiconductors and exists in the chalcopyrite phase. ${ }^{[1-6]} \mathrm{CISe}$ is a vital material to solar cells because of its high absorption coefficient $\left(105 \mathrm{~cm}^{-1}\right)$ and comparable band gap $(1.05 \mathrm{eV})$ in the solar spectrum, which makes CISe as potential candidates for use as an absorber layer in solar cells. Due to its optical properties, this material allows the use of thin films instead of thick slices of bulk silicon. In this way, we can reduce the consumption of materials. CISe and related chalcopyrite compounds have attracted considerable interests for the thinfilm photovoltaic device to achieve a high conversion efficiency of about $20 \%$ based on Ga containing absorber layer (CIGS) ${ }^{[7]}$ Over the past decade, research into the design of CISe based photovoltaic with unique properties has been dramatically intensified. The properties of the CISe absorber layer are significant in determining the efficiency of resulting solar cells. Improved performance may also be achieved by alloying CISe with one of several related compounds, for example, $\mathrm{CuGaSe}_{2}$, to increase the $1.0 \mathrm{eV}$ bandgap of the CISe device. The crystalline silicon solar cells show high production costs of $(5 \$ / \mathrm{W})$, which are compensated by their higher efficiencies. The efficiency of a small area crystalline 
Si solar cell is above $25 \%$ and has been recorded ${ }^{[8]}$ However, the cost involved in the fabrication of such single-crystalline silicon-based solar cells still eludes large scale productions. This leads researchers worldwide to study thin-film solar cells based on chalcogenide materials. The inclusion of the nanocrystalline materials in photovoltaic devices has been proposed to improve the incident photon to current efficiency. ${ }^{[9]}$ Most of the researchers are looking forward to new approaches, such as the use of nanotechnology to improve the device performance. ${ }^{[10-12]}$ Impurities found in CIGS and its alloys are beneficial for solar cell operation. ${ }^{[13]} \mathrm{CISe}$ semiconductor is a crucial material as an absorber layer and offers an advantage of low-cost flexible thin-film solar cells. ${ }^{[14]}$ CISe thin films are essential semiconductor materials for solar cell applications due to their properties such as chemical stability, direct bandgap, and high optical absorption. ${ }^{[15]}$ $\mathrm{CuInSe}_{2}$-based solar cells show long-term stability and the highest conversion efficiencies of all thin-film solar cells approximately $19 \%{ }^{[16,17]}$

This review will outline the current status of research characterizing the production and properties of thin-film polycrystalline CISeand solar cells based on CISe. In the following sections, the most successful chemical methods for thin-film CISedeposition, the properties, and the performance of CISebased solar cells are summarized. In the synthesis, the section highlights various ranges of synthesis parameters of CISe materials. The properties section describes the structural, optical, and electrical properties of the films. The application section analyzes the properties of CISe materials employed in current solar cells. The physical properties of bulk CISe are tabulated in Table1.

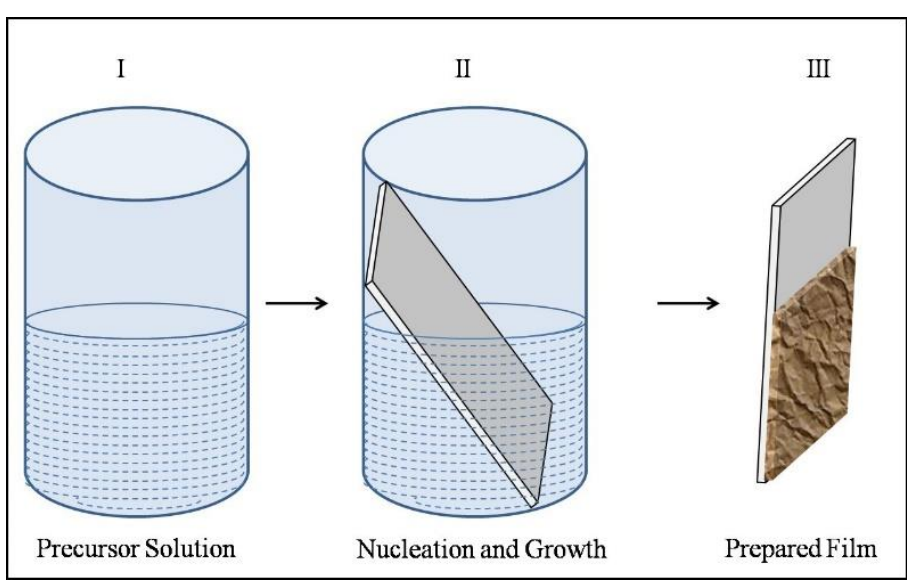

Fig. 1 Chemical bath deposition system schematics.

\section{Chemical synthesis of CISe thin films}

A wide variety of techniques have been used to fabricate CISe thin films including chemical bath deposition (CBD), electrodeposition (ED), ${ }^{[26-39]}$ successive ioniclayer adsorption and reaction (SILAR), spray pyrolysis(SP), three-source evaporation, ${ }^{[40-48]}$ laser annealing, ${ }^{[49-50]}$ flash evaporation, ${ }^{[51-53]}$ spray pyrolysis, ${ }^{[54-59]}$ sputtering, ${ }^{\left[{ }^{60-69]}\right.}$ liquid phase epitaxy, ${ }^{[70-}$ ${ }^{71]}$ electrodeposition, ${ }^{[72-76]}$ screen printing, ${ }^{[77-78]}$ and selenization of metal layers. ${ }^{[79-81]}$ Only chemical methods for the preparation of CISethin films have reported slow-temperature methods that give good quality thin films, and these are reviewed below.

Table 1. Physical properties of CISe thinfilms. ${ }^{[18-25]}$

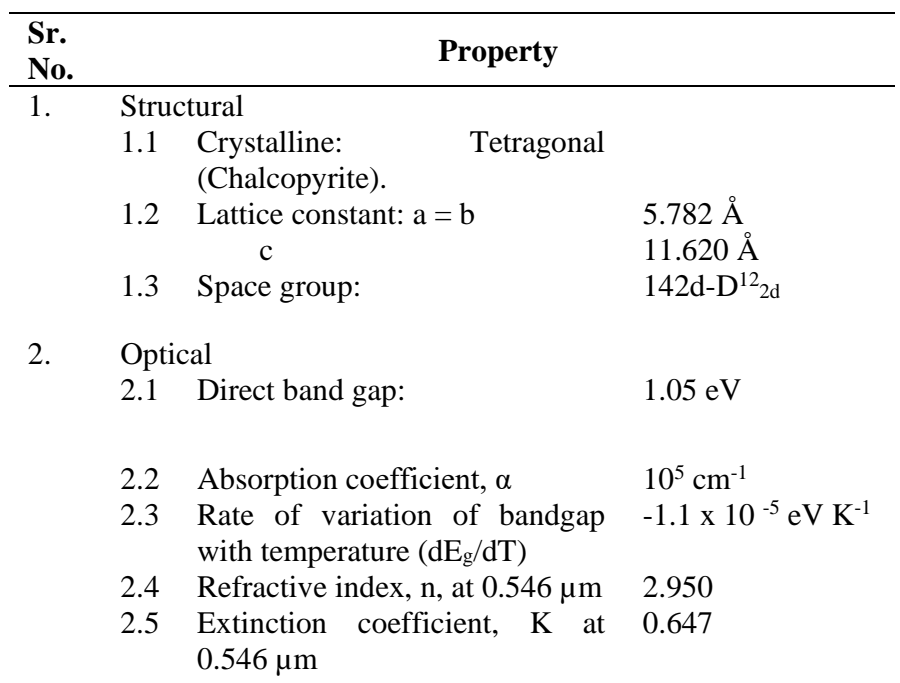

3. Electrical

3.1 Electron affinity, $\chi \quad 4.30 \mathrm{eV}$

3.2 Effective density states at the $10^{19} \mathrm{~cm}^{-3}$ valence band edge $\mathrm{Na}$

3.3 Minority carrier life time $\tau_{\mathrm{p}} \quad 10^{-10} \mathrm{~s}$

3.4 Minority carrier mobility at $300 \quad 320 \mathrm{~cm}^{2} \mathrm{~V}^{-1} \mathrm{~S}^{-1}$ $\mathrm{K}, \mu_{\mathrm{g}}$

3.5 Effective mass of electron ( $\mathrm{n} \quad 0.092$ type)

3.6 Effective mass of hole ( $p$ type) 0.71

3.7 Activation energy $0.18 \mathrm{eV}$

3.8 Electrical resistivity

$\begin{array}{ll}\text { 1) } \mathrm{Cu} \text { rich } & 0.001 \Omega \mathrm{cm} \\ \text { 2) } \mathrm{In} \text { rich } & 100 \Omega \mathrm{cm}\end{array}$

4. Molecular weight

5. Density (D)

6. Color

7. Debye temperature

8. Compressibility

9. Melting point

10. Thermal expansion coefficient, perpendicular $\alpha_{a}$ parallel $\alpha_{c}$

$336.28 \mathrm{~g} \mathrm{~cm}^{-3}$ $5.77 \mathrm{~g} / \mathrm{cc}$

Gray

$221.9 \mathrm{~K}$

$1.4 \times 10^{-11} \mathrm{~m}^{2} \mathrm{~N}^{-1}$

$1260^{\circ} \mathrm{K}$

$11.0 \times 10^{-6} \mathrm{k}^{-1}$

$8.4 \times 10^{-6} \mathrm{~K}^{-1}$

11. Thermal conductivity

$0.086 \mathrm{~W} \mathrm{~cm}^{-1} \mathrm{~K}^{-1}$.

12. Specific heat:

$\mathrm{C}_{1}$

$\mathrm{C}_{2}$

$\mathrm{C}_{3}$

13. Low-frequency dielectric constant $\mathrm{k}$ High-frequency dielectric constant $\varepsilon_{\mathrm{r}}$

$-7.67 \times 10^{-4} \mathrm{~K}^{-1}$

$4.06 \times 10^{-6} \mathrm{~K}^{-1}$

$4.3 \times 10^{-9} \mathrm{~K}^{-1}$

13.6

8.1

14. Bohr exciton radius $\left(\mathrm{R}_{\mathrm{B}}\right)$

$10.6 \mathrm{~nm}$

15. Tetragonal eistortion constant

1.004

\subsection{Chemical bath deposition (CBD)}

CBD method is based on a chemical reaction between the constituent ions. The advantage of this method is low cost and required simple equipment. Precipitation occurs when the ionic product exceeds the solubility product $(\mathrm{Ks})$ of the compound to be deposited. Fig. 1 shows the graphical 
representation of the chemical bath deposition technique. The heterogeneous (film on the substrate) and homogeneous (precipitation in the solution) growth of the films depends on the supersaturation ratio. Heterogeneous growth can be controlled at low supersaturation. ${ }^{\left[{ }^{82]}\right.}$ Sodium selenosulfate $\left(\mathrm{Na}_{2} \mathrm{SeSO}_{3}\right)$ was used as the selenium precursor in CISe ${ }^{[83-84]}$ and CIGS ${ }^{[85]}$ thin films prepared by CBD. Garg et al. ${ }^{[84]}$ prepared CISe films at $40^{\circ} \mathrm{C}$ using cationic precursors such as $\mathrm{Cu}\left(\mathrm{NH}_{3}\right)_{2}{ }^{+4}$ and citrate-complexed $\mathrm{In}^{3+}$ ions. The open circuit voltage $\left(\mathrm{V}_{\mathrm{OC}}\right)$ foran $\mathrm{n}$-Si/p-CISeheterojunction was measured to be about $0.3 \mathrm{~V}$ after the post-annealing of the CISe film at $520^{\circ} \mathrm{C}$ in air. Bhattacharya et. al. ${ }^{[83]}$ used solutions containing $\mathrm{Cu}\left(\mathrm{NO}_{3}\right)_{2}, \mathrm{In}\left(\mathrm{SO}_{3} \mathrm{NH}_{2}\right)_{3}, \quad \mathrm{Ga}\left(\mathrm{NO}_{3}\right)_{3}, \quad \mathrm{Na}_{2} \mathrm{SeSO}_{3}, \quad$ triethanolamine, $\mathrm{NH}_{4} \mathrm{OH}$, and/or $\mathrm{NaOH}$ for the preparation of $\mathrm{Cu}$ rich CIGS film. These films were used as absorbers in solar cells that showedan efficiency of $7.3 \%{ }^{[85]}$ Several review articles discussing the status of CBD have appeared in the literature. The preparation parameters such as $\mathrm{pH}$, deposition time, and deposition temperature have been studied to obtain good quality CISe films. The complexing agents are used to increase the reaction rate of the solution. Hankare et al. prepared a CISe film by using tartaric acid as a complexing agent. ${ }^{\left[{ }^{[8]}\right.}$ In the reaction bath, $\mathrm{Cu}^{+}$and $\mathrm{In}^{3+}$ were complexed with tartaric acid in the form of the water-soluble tartrate complex, which controls the metal ion concentration. The dissociation of sodium selenosulphate, as well as tartrate complex in alkaline medium, takes place at room temperature. The process is controlled by the slow release of $\mathrm{Cu}^{+}, \mathrm{In}^{3+}$, and $\mathrm{Se}^{2-}$ ions in the solution. The hydrazine hydrate acts as a complementary complexant, which improves the compactness and adherence of the film.

The CISe micrograph shows a compact structure composed of a single type of small, densely packed microcrystal. The grains are well defined, spherical, and of almost similar size. The annealed samples showed an improvement in grain size. The average crystallite size of the annealed CISe thin-film was found to be $331 \AA$. The CBD method is useful to deposit binary, ternary as well as quaternary films. By using this method, many researchers prepared different morphologies of the CISe films. Bhari et al. showed the granular nature of the CISefilms. ${ }^{[87]}$ The solution growth technique is used to deposit the CISe film on a glass substrate. The process involves the reaction of $\mathrm{Cu}^{+}$with $\mathrm{In}^{3+}$ and $\mathrm{Se}^{2-}$ ions in deionized water solution. The temperature of the solution was held at $60^{\circ} \mathrm{C}$ for about $2 \mathrm{hr}$ and uniform CISe films were obtained on a glass substrate. The preparative parameter of this method areshown in Table 2. For example, Chauhan et al. ${ }^{[88]}$ deposited CISe films by CBD using cupric chloride dihydrate, indium(III) chloride, anhydrous elemental selenium, triethanolamine, sodium sulfite, and hydrochloric acid. All the prepared films have tetragonal unit cell structure with lattice parameter $\mathrm{a}$ and $\mathrm{c}$ to be 5.782 and $11.621 \AA$, respectively and the crystallite size estimated by Scherrer's formula (10.84 nm) and Hall-Williamsons relation (9.95 nm). The microtopography thin films studiedby optical microscope and SEM techniques clearly showed that the film deposition is uniform and the film covers the entire substrate surface. The analysis of the recorded AFM 2D image of the thin film surface showed spherical grains having coalescence between them. The 3D AFM image showed spike-like growth on the film surface. The obtained direct optical bandgap energy from UV-vis-NIR spectroscopy is $1.39 \mathrm{eV}$. Hall effect measurement analysis confirmed the semiconducting and $\mathrm{p}$ type nature of the as-deposited CISe thin films.

The advantages of the CBD method are: 1 . CBD does not require sophisticated instrumentation. 2. Electrical conductivity of the substrate materials is not an important criterion. 3. It is applicable for large area deposition. 4. The process is slow that facilitates a better orientation of crystallites with improved grain structures. 5. As very dilute solutions are used in the process, the method offers minimum toxicity and occupational hazards. The disadvantages of the CBD method are: 1. Wastage of solution after every deposition. 2. Proper substrate is needed to have good adherents.

\subsection{Chemical electro-deposition (CED)}

CED is a three-electrode system, namely cathode, anode, and a reference electrode. The most commonly used reference electrodes are $\mathrm{Ag} / \mathrm{AgCl}$ and calomel electrode. Fig. 2 shows the schematic diagram of chemical deposition. This method is widely used in the electronics industry to depositing conducting and magnetic layers. The CED of CISe is costeffective, time-saving, and adequate for safety concerns. It is proved to be a promising way to prepare CISe films. Electrodeposited copper is now the material of choice for interconnects in the ultra largescale integrated circuit. The main advantage of this method is to control the sample composition.

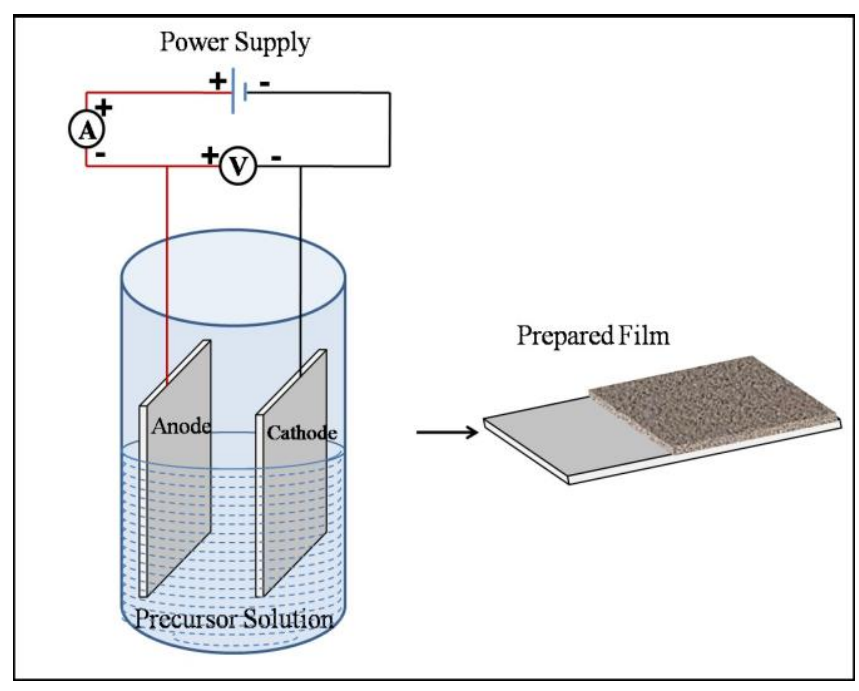

Fig. 2 Chemical electrodeposition system schematics. 
Table 2. The preparative parameter for the deposition of CISe using CED.

\begin{tabular}{|c|c|c|c|c|}
\hline Sr. No. & Precursors & $\begin{array}{l}\text { Subsrate \& } \\
\text { Temp. }\left({ }^{\circ} \mathrm{C}\right)\end{array}$ & Results & Ref. \\
\hline 1 & $\begin{array}{l}0.040 \mathrm{M} \mathrm{CuCl}_{2}, 0.008 \mathrm{M} \\
\mathrm{InCl}_{3}, 0.008 \mathrm{M} \mathrm{H}_{2} \mathrm{SeO}_{3} \\
(\mathrm{pH} \sim 1.5)\end{array}$ & $\begin{array}{r}\text { Ti } \\
\text { R.T. }\end{array}$ & Polycrystalline & {$[116]$} \\
\hline 2 & $\begin{array}{l}10 \mathrm{mM} \mathrm{CuSO}_{4}, 25 \mathrm{mM} \\
\mathrm{In}_{2}\left(\mathrm{SO}_{4}\right)_{3}, 30 \mathrm{mM} \mathrm{SeO}_{2} \\
(\mathrm{pH} \sim 1)\end{array}$ & $\begin{array}{c}\mathrm{Ti} \\
50-55\end{array}$ & $\begin{array}{l}\text { The as-deposited films deposited between } 0 \text { to }-0.6 \mathrm{~V} \text { (SCE) showed } \\
\text { the XRD reflection of CISe and } \mathrm{Cu}_{3} \mathrm{Se}_{2} \text { where as only those of CISe } \\
\text { were found for films deposited at }-0.8 \mathrm{eV} \text {. }\end{array}$ & {$[126]$} \\
\hline 4 & $\begin{array}{l}3.7 \mathrm{mM} \mathrm{CuCl}_{2}, \\
22 \mathrm{mM} \mathrm{InCl}_{3}, 3.6 \mathrm{M} \mathrm{SeO}_{2} \\
(\mathrm{pH} \sim 1.5)\end{array}$ & $\begin{array}{r}\mathrm{Ti} \\
\text { R.T. }\end{array}$ & $\begin{array}{l}\text { binary phases of } \mathrm{In}_{6} \mathrm{Se}_{7} \text { together with CISe. } \\
\text { rough surface morphology. }\end{array}$ & [127] \\
\hline 7. & $\begin{array}{l}3 \mathrm{mM} \mathrm{CuSO}_{4}, 6 \mathrm{mM} \mathrm{In}_{2}\left(\mathrm{SO}_{4}\right)_{3} \\
5 \mathrm{mM} \mathrm{SeO}_{2}, 0.4 \mathrm{M} \mathrm{C}_{6} \mathrm{H}_{8} \mathrm{O}_{7} \\
(\mathrm{pH} \sim 1.7)\end{array}$ & $\begin{array}{l}\mathrm{Ti} \\
\text { R.T. }\end{array}$ & $\begin{array}{l}\text { The deposition rate increase, as well as the current efficiency } \\
\text { increase, but the film morphology did not change. }\end{array}$ & {$[131]$} \\
\hline 8. & $\begin{array}{l}5-10 \mathrm{mM} \mathrm{CuSO}_{4}, 10-20 \mathrm{mM} \\
\mathrm{In}_{2}\left(\mathrm{SO}_{4}\right)_{3}, 10-20 \mathrm{mM} \mathrm{SeO}_{2} \\
60-80 \mathrm{mM} \mathrm{K}_{2} \mathrm{SO}_{4}, 0.8 \mathrm{mM} \\
\mathrm{Na}_{3} \mathrm{C}_{6} \mathrm{H}_{5} \mathrm{O}_{7},(\mathrm{pH} \sim 1)\end{array}$ & $\begin{array}{l}\mathrm{Ni} / \mathrm{Ti} \\
\text { R.T. }\end{array}$ & $\begin{array}{l}\text { The formation of smooth layers of the crystalline compound was } \\
\text { correlated with a plateau on the polarization curve. } \\
\text { Films deposited outside the potential range corresponding to the } \\
\text { plateau had poor crystallinity. }\end{array}$ & [132] \\
\hline 9. & $\begin{array}{l}3 \mathrm{mM} \mathrm{Cu}\left(\mathrm{NO}_{3}\right), 3 \mathrm{mM} \mathrm{InCl}_{3}, 5 \\
\mathrm{mM} \mathrm{SeO}_{2}, 0.4 \mathrm{M} \mathrm{C}_{6} \mathrm{H}_{8} \mathrm{O}_{7} \\
(\mathrm{pH} \sim 2.0)\end{array}$ & $\begin{array}{l}\text { Mo } \\
\text { R.T. }\end{array}$ & $\begin{array}{l}\text { The currents corresponding to the reduction of } \mathrm{Se}^{4+} \text { to } \mathrm{Se} \text { on CISe, } \\
\text { was smaller than on Mo which was attributed to the formation of the } \\
\text { insulating film. The effect of the substrate found in the } \\
\text { electrochemical reaction. }\end{array}$ & [133] \\
\hline 13 & $\begin{array}{l}\mathrm{CuSO}_{4}, \mathrm{In}_{2}\left(\mathrm{SO}_{4}\right)_{3} \\
\mathrm{SeO}_{2} \cdot(\mathrm{pH} \sim 1)\end{array}$ & $\begin{array}{l}\text { Gr. } \\
\text { R.T }\end{array}$ & $\begin{array}{l}\text { Annealing under Ar at or above } 400{ }^{\circ} \mathrm{C} \text { for } 15 \mathrm{~min} \text { caused the loss } \\
\text { of excess Se and improved the surface morphology. }\end{array}$ & {$[135]$} \\
\hline 14 & $\begin{array}{l}0.73 \mathrm{mM} \mathrm{CuCl} \\
5.27 \mathrm{mM} \mathrm{InCl}_{3} \\
0.9 \mathrm{mM} \mathrm{SeO}_{2}(\mathrm{pH} \sim 1)\end{array}$ & $\begin{array}{l}\text { Mo } \\
\text { R.T. }\end{array}$ & $\begin{array}{l}\text { Amorphous films; p-type, } \\
\text { high carrier concentration of } 3.63 \times 10^{20} \mathrm{~cm}^{-3} \text { open-circuit voltage } \\
0.188 \mathrm{~V} \\
\text { short circuit density } 0.056 \mathrm{~mA} \mathrm{~cm}-2\end{array}$ & [136] \\
\hline 15 & $\begin{array}{l}\mathrm{CuCl}, \mathrm{InCl}_{3}, \mathrm{Na}_{2} \mathrm{SeSO}_{3} \\
\mathrm{NH}_{4} \mathrm{OH}, \mathrm{C}_{6} \mathrm{H}_{8} \mathrm{O}_{7} \\
(\mathrm{pH} \sim 9)\end{array}$ & $\begin{array}{l}\text { G } \\
\text { R.T. }\end{array}$ & $\begin{array}{l}\text { Chalcopyrite. } \\
\mathrm{V}_{\mathrm{oc}}=0.165 \\
\mathrm{~J}_{\mathrm{sc}}<1 \mathrm{~mA} \mathrm{~cm}\end{array}$ & [137] \\
\hline 16 & $\begin{array}{l}0.012 \mathrm{M} \mathrm{CuCl}_{2} \\
0.025 \mathrm{M} \mathrm{InCl}_{3} \\
0.025 \mathrm{M} \mathrm{H}_{2} \mathrm{SeO}_{3} \\
(\mathrm{pH} \sim 1.5)\end{array}$ & $\begin{array}{c}G \\
24\end{array}$ & $\begin{array}{l}\text { Electrodeposited CISe thin films were characterized by AES depth } \\
\text { profiling to study the concentration gradient of the element present } \\
\text { in the film. }\end{array}$ & {$[138]$} \\
\hline 17 & $\begin{array}{l}3 \mathrm{mM} \mathrm{CuSO}_{4}, 3 \mathrm{mM} \mathrm{In}_{2}\left(\mathrm{SO}_{4}\right)_{3} \\
5 \mathrm{mM} \mathrm{SeO}_{2}, 0.4 \mathrm{M} \mathrm{C}_{6} \mathrm{H}_{8} \mathrm{O}_{7}\end{array}$ & $\begin{array}{l}\text { Mo } \\
\text { R.T. }\end{array}$ & $\begin{array}{l}\text { After heat treatment of the sample produces elemental selenium loss } \\
\text { has been detected together with an enhancement of the allowed } \\
\text { direct optical transition. }\end{array}$ & [98] \\
\hline 18. & $\begin{array}{l}5 \mathrm{mM} \mathrm{CuCl}_{2}, 10 \mathrm{mM} \mathrm{InCl}_{3}, \\
5 \mathrm{mM} \mathrm{SeO} 2, \mathrm{HCl} \\
(\mathrm{pH} \sim 1.5-2.5)\end{array}$ & $\begin{array}{l}\text { Pl } \\
\text { R.T. }\end{array}$ & $\begin{array}{l}\text { Here } 3 \mathrm{D} \mathrm{TiO}_{2} / \mathrm{CISe} \text { nano-composite solar cell obtained. Current } \\
\text { studies focus on introducing a buffer layer and on rapid thermal } \\
\text { annealing in } \mathrm{S} \text {. }\end{array}$ & [139] \\
\hline
\end{tabular}


19

$\mathrm{CuSO}_{4}, \mathrm{In}_{2}\left(\mathrm{SO}_{4}\right)_{3}$,

$\mathrm{SeO}_{2}$,

20.

$1 \mathrm{mM} \mathrm{CuCl}, 5 \mathrm{mM} \mathrm{InCl}_{3}$, $1 \mathrm{mM} \mathrm{SeO}_{2}, 3.5 \mathrm{M} \mathrm{KSCN}$ (pH 4.0) (pH - 6.5-7)
$3 \mathrm{mM} \mathrm{Cu}\left(\mathrm{NO}_{3}\right)_{2}$,

$3 \mathrm{mM} \mathrm{In}\left(\mathrm{NO}_{3}\right)_{2}$,

$5 \mathrm{mMSeO}_{2}, \mathrm{HNO}_{3}$,

$\mathrm{NaOH} .(\mathrm{pH} \sim 8.5)$

$10 \mathrm{mM} \mathrm{CuSO}_{4}$ $25 \mathrm{mM} \mathrm{In}_{2}\left(\mathrm{SO}_{4}\right)_{3}, 30 \mathrm{mM}$ $\mathrm{SeO}_{2} .(\mathrm{pH} \sim 1)$

$0.005 \mathrm{M} \mathrm{CuCl}_{2}, 0.005 \mathrm{M}$ $\mathrm{InCl}_{3}, 0.01 \mathrm{M} \mathrm{SeO}_{2}$, ( $\mathrm{pH}-1.5)$

$2.56 \mathrm{mM} \mathrm{CuCl} 2,4.80 \mathrm{mM}$ InCl3, 4.47 mM SeCl4, 0.20 $\mathrm{mM} \mathrm{LiCl}$

1.14-4.55 mM CuCl $2,3.75$ $\mathrm{mM} \mathrm{In}_{2}\left(\mathrm{SO}_{4}\right)_{3}, 6.89-13.78 \mathrm{mM}$ $\mathrm{H}_{2} \mathrm{SeO}_{3}, 0.7 \mathrm{M} \mathrm{LiCl}$, 1 mM BTA (pH - 3)

$2 \mathrm{mM} \mathrm{CuCl}_{2}, 0.6 \mathrm{mM} \mathrm{InCl}_{3}, 4$ $\mathrm{mM} \mathrm{SeO}_{2}, 15 \mathrm{mM} \mathrm{C}_{6} \mathrm{H}_{5}$ $\mathrm{Na}_{3} \mathrm{O}_{7}, \mathrm{CitNa}, \mathrm{NaOH}, \mathrm{HCl}$.

$1 \mathrm{mM} \mathrm{CuCl}_{2}, 3 \mathrm{mM} \mathrm{InCl}_{3}$, $1.7 \mathrm{mM} \mathrm{SeO}_{2} \cdot(\mathrm{pH}-2)$

$3 \mathrm{mM} \mathrm{CuCl}_{2}, 6 \mathrm{mM} \mathrm{InCl}_{3}$, $5 \mathrm{mM} \mathrm{SeO}_{2}, 0.4 \mathrm{M}$ Sodium citrate. $\mathrm{HCl}, \mathrm{NaOH}$ (pH: 4-6)

$1.0 \mathrm{mM} \mathrm{CuSO}_{4}, 3.3 \mathrm{mM}$ $\mathrm{In}_{2} \mathrm{SO}_{4}, 3.3 \mathrm{mM} \mathrm{SeO}$.

$1 \mathrm{mM} \mathrm{CuCl}_{2}, 5 \mathrm{mM} \mathrm{InCl}_{3}$, $1 \mathrm{mM} \mathrm{SeO}_{2}, 1 \mathrm{M}$ TEA, $0.1 \mathrm{Na}-$ Citrate, $\mathrm{HCl}$ $(\mathrm{pH}=1.65)$
ITO Hybrid PV structures based on polycrystalline photo absorber R.T. CISe\& electrically conductive polypyrrole (PPY) were prepared.

Mo \& Pl The copper content in the solution increase with the increasing bath 20-80 temperature. Amorphous nature with small grains size observed in XRD without annealing.

ITO TEA has added to the solution as a complexing agent to improve the R.T. crystallinity and uniformity of the layer.

$\mathrm{SnO}_{2} \quad$ Multiple phases

150

ITO, The effect of the concentration of indium ions in the electrolyte on 75 the currents of the cathodic and anodic peaks was studied with the concentration of indium ions. The composition of the compound formed was confirmed by the X-ray phase and electron microprobe analyses. Photosensitivity was found, with the maximum short circuit current $6 \mathrm{~mA}$ and an open circuit potential of $0.4 \mathrm{~V}$.

ITO, Al, XRD shows the amorphous nature of all the films. An additional steel. phase attributed to the $\mathrm{In}_{2} \mathrm{O}_{3}$ is was also detected. SEM reveals that R.T. the CISe film on aluminum shows particles of great size with a more remarkable cauliflower appearance. $\mathrm{An} \mathrm{E}_{\mathrm{g}}$ of $1.09 \mathrm{eV}$ was determined which become p-type semiconductor, appropriate material for photovoltaic application.

$\mathrm{Ti} \quad$ chalcopyrite phase

50-55 exhibited poor surface morphologies.

Ti Chalcopyrite structure (113), (220), and (117). XPS shows the R. T. chemical and stoichiometric change occurring at the top surface layers within the probing depth of $30 \AA$

Structure: cauliflower type.

FTO

From XRD that the material comprised $\mathrm{Cu}$-Se binaries and CISe phases. XRF identified increasing indium content at more negative deposition voltages.

ITO

R.T

the bulk concentration of $\mathrm{Cu}$ and Se and deposition potentials on the stoichiometric properties were discussed.

ITO

The result showed that the reduction of $\mathrm{Cu}^{2+}$ to $\mathrm{Cu}^{+}$at one potential

R.T. point of $-800 \mathrm{mV}$ In XRD, the film shows 112, 312, 220 peaks.

$\mathrm{TiO}_{2} \quad$ A cross-section thickness of CISethat was found at $3.16 \mu \mathrm{m}$. The R.T. bandgap values of CISe was found to be $1.04 \mathrm{eV}$.

$\mathrm{TiO}_{2} \quad$ chalcopyrite phase.

R.T. The optical band gap lies between 1.02 and $1.45 \mathrm{eV}$.

ITO The photovoltaic characteristics were measured were,

R.T. $\quad \mathrm{J}_{\mathrm{sc}}=0.56 \mathrm{~mA} / \mathrm{cm}^{2}, \mathrm{~V}_{\mathrm{oc}}=31.3 \mathrm{mV} . \mathrm{V}_{\mathrm{bi}}=2.15 \mathrm{eV}$, $\mathrm{N}_{\mathrm{D}}=3.67 \times 10^{17} \mathrm{~cm}^{-3}$

Plastic The bandgap of the CISe film was about $1.18 \mathrm{eV}$.

[140]

R.T.
The stoichiometric relation between the $\mathrm{Cu}$, In, and $\mathrm{Se}$ atom is directly related to the CED conditions and concentrations. CED of CISe based thin films is commonly carried out by using an aqueous solution that contains a simple compound of $\mathrm{Cu}^{+}$or $\mathrm{Cu}^{2+}$ and $\mathrm{In}^{3+}$ ions. Mostly sulfates or chlorides were used in CED. In this method, the $\mathrm{Na}_{2} \mathrm{SeSO}_{3}$ is dissolved into a mildly acidic solution in the form of $\mathrm{HSeO}_{3}$ and sodium sulfite $\left(\mathrm{Na}_{2} \mathrm{SO}_{3}\right)_{\cdot}{ }^{\left[{ }^{[8]}\right.}$ According to the Nernst equation, the electrode potentials for selenium and copper will lead to the deposition of indium. This problem has been 
overcome by using a complexing agent (like citric acid, triethanolamine, $\mathrm{CN}^{-}$, etc) to shift the copper deposition potential in the negative direction close to the In deposition potential. Cathodic CED of CISe is based on the co-reduction of $\mathrm{Cu}^{2+} / \mathrm{Cu}$, $\mathrm{In}^{3+} / \mathrm{In}$, and the reduction of $\mathrm{HSeO}^{2-}$ species. ${ }^{[90-91]}$ The available free energy from compound formation results in a shift of the metal deposition potentials to positive values (relative to the standard potentials $\mathrm{E}^{0}$ ). When the external power supply drives a current through the cell, metal ions are reduced to metal atoms at one of the electrode (cathode) and chalcogen ions to the other electrode (anode).

According to the Nernst equations: Reaction ( $\mathrm{E}^{0} \mathrm{vs}$ SHE)

$$
\begin{array}{cc}
\mathrm{Cu}^{2+}{ }_{\text {(aq.) }}+2 \mathrm{e}^{-} \rightarrow \mathrm{Cu}_{(\mathrm{S})} & 0.337 \mathrm{eV} \\
\mathrm{In}^{3+}{ }_{\text {(aq.) }}+3 \mathrm{e}^{-} \rightarrow \mathrm{In}(\mathrm{s}) & -0.342 \mathrm{eV}
\end{array}
$$

$\mathrm{HSeO}^{2-}+4 \mathrm{e}^{-}+4 \mathrm{H}^{+}+\mathrm{OH}^{-} \rightarrow \mathrm{Se}_{(\mathrm{s})}+3 \mathrm{H}_{2} \mathrm{O} \quad 0.741 \mathrm{eV}(3)$

The electrode potentials of selenium and copper are more positive than that of indium. The simultaneous deposition of $\mathrm{Cu}$, In and $\mathrm{Se}$, adjustment of $\mathrm{pH}$, and concentration of electrolyte can make the potential close to each other. If the cathode potential is made more negative, the rate of reaction increases and if it is made more positive, the reverse reaction will be possible.

$$
\mathrm{Cu} \text { (solid) } \rightarrow \mathrm{Cu}^{2+}+2 \mathrm{e}^{-} \text {and In (solid) } \rightarrow \mathrm{In}^{3+}+3 \mathrm{e}^{-}
$$

The potential, at which the rates of the forward and reverse reaction are equal, is called equilibrium potential. It depends on the concentration of $\mathrm{Cu}^{2+}, \mathrm{In}^{3+}$, and $\mathrm{Se}^{2-}$ ions in the electrolyte which is denoted by $\mathrm{M}$.

$$
\mathrm{E}_{\mathrm{eq}}=\mathrm{E}^{01}+(\mathrm{KT} / \mathrm{ne})(\ln \mathrm{M})
$$

where $\mathrm{E}^{01}$ is the Formal potential and $\mathrm{M}$ is the concentration of the ions.

The rate of metal deposition is controlled by the overpotential $(\mathrm{V})$ given by:

$$
\mathrm{V}=\mathrm{E}_{\mathrm{eq}}-\mathrm{E}
$$

where $\mathrm{E}$ is the potential applied to the electrode.

The process of decomposition of an electrolyte depends on passing an electric current through its aqueous solution. The potential ranges of various compounds depend on various factors such as total conductivity of the solution, cathode surface area (ohmic drops), electrolyte temperature, ${ }^{[91]}$ etc. The complexing agent used in the solution shifts the reduction potential of the $\mathrm{Cu}$ and In ions close together and improves the quality of the film. The results show that single phase $\mathrm{CuInSe}_{2}$ can be obtained by suitably controlling deposition potential and heat treatment. The estimated number of electrons transferred for the overall reaction of $\mathrm{CuInSe}_{2}$ deposition was $13{ }^{[92]}$ The complexing agents including citric acid, ammonia, tri-ethanolamine, ethylene-di-mine, ethylenedi-amine tetra-acetic acid (EDTA), thiocyanate, etc. are used in CED. One-step CED of *** (CIS)is mostly carried out potentiostatically at RT by using sulfates copper selenides obtained are depending on the solution composition and the diffusion conditions ${ }^{[93-104]}$ or chlorides, ${ }^{[105-114]}$ galvanostatic ${ }^{[106,107,115]}$ and pulsed $\mathrm{CED}^{[102,113,114]}$ have been used for the preparation of CISe film. In CED, $\mathrm{Cu}^{2+}$ compounds are used more frequently than $\mathrm{Cu}^{+}$compounds because of the limited solubility and instability of $\mathrm{Cu}^{+}$ions in aqueous solutions. The Se precursor $\mathrm{SeO}_{2}$ is dissolved into mildly acidic solutions in the form of $\mathrm{HSeO}^{3-}{ }^{[116]}$ Sometimes, a supporting electrolyte as sulfate $\left(\mathrm{K}_{2} \mathrm{SO}_{4}\right)$ or chlorides was used. ${ }^{[117]}$ Beyhan et al. studied the effect of the complexing agent on the stoichiometric ratio of the CISe thin films. ${ }^{[118]}$ The solution contains $\mathrm{CuCl}_{2}, \mathrm{In}_{2}\left(\mathrm{SO}_{4}\right)_{3}, \mathrm{LiCl}$, benzotriazole (BTA) dissolved in $\mathrm{pH}$ buffer ( $\mathrm{pH}-3)$ for the preparation of CISe film.This film was prepared by using a three-electrode such as counter electrode (Pt gauze), reference electrode (SCE), and ITO substrate ITO at room temperature without stirring the electrolyte solution. The deposition potential and concentration of the $\mathrm{Cu}$ and Se can affect the surface composition of the films. The $\mathrm{Cu}$ gives a complex reaction with BTA for the enhancement of the reduction reaction rate.

A uniform and transparent film with good stoichiometry $\left(\mathrm{In}_{1} \mathrm{Cu}_{1} \mathrm{Se}_{1.8}\right)$ was obtained under $-0.55 \mathrm{~V} / \mathrm{SCE}$ at $\mathrm{pH} 3$. Huang et al. prepared CISe film on flexible ( $\mathrm{Au}$ coated plastic) substrate by the CED method. ${ }^{[119]}$ They also studied the effect of the complexing agent i.e. TEA, Na-citrate on the quality of the films. The buffer agent TEA was used to suppress the reduction of copper ions during the growth process. Also, the concentration of $\mathrm{Na}$ citrate added into the bath was varied from 0 to $0.2 \mathrm{M}$ during the growth process to avoid the $\mathrm{pH}$ variation. The CISe filmswere formed on the plastic substrates with different concentrations of TEA in bath solution. The dense distribution on the surface of the CISe film was observed. The sparse distribution and cloud-like precipitation on the surface of the films are shown in this result. This result is due to the high concentration of TEA, which causes a colloid state in the electrolyte. The precipitation of the colloid state electrolyte adheres to the surface of the substrate during co-deposition. Thus the quality of the film is degraded. From the image observation, it was concluded that the 1M TEA optimal concentration is controlled.

Sodium citrate was added into the growth solution to control the $\mathrm{pH}$ value of the solution. In the SEM micrograph of the CISe film with various concentrations of the Na-Citrate, the white and column-like precipitation was observed on the surface of the CISe film. This indicates the hydrogen evolution, which produces indium hydroxide precipitations on the surface of the film. This precipitation fully disappeared when $0.1 \mathrm{M} \mathrm{Na}$-citrate was added in the bath. The quality of CISe film can be improved by adding $0.1 \mathrm{M} \mathrm{Na-Citrate.} \mathrm{The}$ morphology and composition of CISe films depend on the deposition voltage. Wellings et al. ${ }^{[120]}$ discussed the morphology variation of the films concerning different deposition voltages. They prepared CISe film from ethylene glycol at $150^{\circ} \mathrm{C}$ by the $\mathrm{ED}$ method. Although the films were deposited at $150^{\circ} \mathrm{C}$, no noticeable improvement of the CISe was observed, suggesting the growth from aqueous media at room temperature to be preferable. SEM was carried out to the layer to investigate the surface morphology. The presence of 
individual crystallites $10-20 \mathrm{~nm}$ in size is observed. Different morphologies were compared to the film deposited at $-0.80 \mathrm{~V}$ vs SCE. Larger crystallites were formed around $0.5-1.0 \mu \mathrm{m}$. The SEM image of the layer deposited at $-1.00 \mathrm{~V}$ vs SCE shows a crystallite size of 0.2 to $0.5 \mu \mathrm{m}$ with an additional surface object around $1.0 \mu \mathrm{m}$.Dharmadasa et al. prepared 25 samples of CISe films using a single electrolyte by the ED technique. ${ }^{[121]}$ A typical electrolyte can be formed by using $0.001 \mathrm{M} \mathrm{CuSO}_{4}, 0.004 \mathrm{M} \mathrm{In}\left(\mathrm{SO}_{4}\right)_{3}$, and $0.008 \mathrm{M}$ $\mathrm{H}_{2} \mathrm{SeO}_{3}$,which are dissolved in de-ionized water. The uniform and well adhesive layers are produced for some voltage regions. The layers grown are disordered and dissolved in the electrolyte at voltages $\sim 1.90 \mathrm{~V}$ and $(2.53-2.56) \mathrm{V}$. This indicates that these voltages do not help grow stable layers for the fabrication of solar cell. The surface morphologies of layer from 2.03, 2.46, and $2.70 \mathrm{~V}$ were studied by using AFM images. At these three voltages, the nanoparticles were grown spherical. Araujo et al. deposited CISe films on different substrates like ITO, Al, and Steel, etc. from the alkaline medium by using the CED technique. ${ }^{[122]}$ From SEM images, a uniform deposition with a compact surface on ITO substrates can be observed. The structure exhibits multi nuclei with uniform size and is cauliflower-shaped at the steel substrate. This was a more compact film. The particles show a great size with a more remarkable cauliflower appearance on an $\mathrm{Al}$ substrate.

The structural properties of the CISe film depend on the post-deposition treatments. De Silva et al. ${ }^{[123]}$ prepared CISe films by CED technique at room temperature. They discussed the variation of structural properties of the film with changing the annealing temperature in air and argon media. In XRD, if the samples were annealed at a temperature above $350{ }^{\circ} \mathrm{C}$ in air media, there was a drop of CISe peak (115) intensity and some additional peaks appeared, which indicates the formation of other compounds such as $\mathrm{In}_{2} \mathrm{O}_{3}$ and $\mathrm{CuO}$. The formation of CISe was strong when annealed at $350{ }^{\circ} \mathrm{C}$ but completely dissociates at temperature $500{ }^{\circ} \mathrm{C}$. But at argon media, the CISe peak can be observed even after annealing at $500^{\circ} \mathrm{C}$ without forming the secondary phase. They also showed that the deposition potential influences the atomic composition of In and Se present in the film. The indium content gradually increases while the composition of $\mathrm{Se}$ gradually decreases when the negative values of the deposition potential are increased. There was no noticeable variation in the $\mathrm{Cu}$ concentration with an increase in deposition potential. SEM images show the cauliflower type features of various sizes of the particles up to $6 \mu \mathrm{m}$. CISe films were annealed at $600{ }^{\circ} \mathrm{C}$ and cracks were observed, visible as thin lines. Saucedo et al. studied the phase evolution in the growth of CISe film on polycrystalline MO by CED technique. ${ }^{[124]}$ The solution contains $1 \mathrm{mMCuSO}_{4}, 6 \mathrm{mM} \mathrm{In}_{2}\left(\mathrm{SO}_{4}\right)_{3}, 1.7 \mathrm{mM} \mathrm{SeO}_{2}$, and a supporting sulfate electrolyte. The deposition potential was fixed $-0.9 \mathrm{~V} / \mathrm{MSE}$ and the charge density was varied up to $5{\mathrm{C} . \mathrm{cm}^{2}}^{2}$ to control the thickness from 100 to $4350 \mathrm{~nm}$. This experiment was performed at room temperature. The growth process of the film can be divided into three well-separated stages. In the first stage (up to $100 \mathrm{~nm}$ ), the formation of the $\mathrm{Cu}$ rich binary phase $\left(\mathrm{Cu}_{2} \mathrm{Se}\right)$. This implies that the nucleation process is mostly controlled by the $\mathrm{Cu}$ rich binary than the CISe chalcopyrite. $\mathrm{Cu}$ concentration is more as compared to the In concentration. But, in the second stage (after $100 \mathrm{~nm}$ ), the In concentration starts to grow as well as the $\mathrm{Cu}$ concentration decreases. Se concentration is considered almost constant throughout the entire layer. Indium starts to participate in the overall process when the concentration of Se is significantly higher, and then the formation of ordered vacancy compound (OVC) and chalcopyrite phase starts. During the first stage, the contribution of $\mathrm{Cu}_{2} \mathrm{Se}$ diminishes with time, and the OVC phase slowly increases and the elemental Se decreases at the same time. In the third stage (after $800 \mathrm{~nm}$ ), quasi-steady state occurrs and is maintained up to the final growth steps. Before the end of the third stage, CuSe binary phase starts to dominate the phase's formation. But the OVC and the free elemental Se decreases. The $\mathrm{Cu}_{2} \mathrm{Se}$ binary seems to be thermally sensitive, decomposing at $200^{\circ} \mathrm{C}$, being the key factor for the OVC vanishing, and the formation of the CISe chalcopyrite phase. The Raman spectra before thermal treatment (BTT)and after thermal treatment (ATT) ofCISe film show that the OVC signal decreases and the CISe signal increases in ATT. Valdeset al. have prepared $\mathrm{TiO}_{2} / \mathrm{In}_{2} \mathrm{Se}_{3} / \mathrm{CISe}$ heterojunction by using CED and chemical SP technique. ${ }^{[125]} \mathrm{In}$ this work, a dense $\mathrm{TiO}_{2}$ layer is deposited by the SP method. After that, $\mathrm{In}_{2} \mathrm{Se}_{3}$ was electrodeposited on $\mathrm{TiO}_{2}$. Lastly, CISe was electrodeposited on the $\mathrm{In}_{2} \mathrm{Se}_{3}$ film. The $\mathrm{In}_{2} \mathrm{Se}_{3}$ acting as a buffer layer was used to improve the conversion efficiency. $\mathrm{In}_{2} \mathrm{Se}_{3}$ thin films were electrodeposited in between the $\mathrm{TiO}_{2} / \mathrm{CISe}$ p-n heterojunction to block the electron backflow and lower the interfacial recombination produced after the illumination. This film was annealed in Se atmosphere to improve the crystallinity of the film. The $\mathrm{Cu}$ rich and Se rich phases were removed after etching the films in a $0.5 \mathrm{M} \mathrm{KCN}$ aqueous solution. The $\mathrm{In}_{2} \mathrm{Se}_{3}$ films are homogeneous and formed by nanosized particles. A crosssection view gives the thickness of the layers. The average value results in $0.47 \mu \mathrm{m}$ for the thickness of the $\operatorname{In}_{2} \mathrm{Se}_{3}$ deposited during $15 \mathrm{~min}$ at a $-0.8 \mathrm{~V}$ and $3.16 \mu \mathrm{m}$ for CISe deposited for $60 \mathrm{~min}$. The advantages of electrodeposition are: 1. It makes it possible to grow uniform films on different substrates and over large and/or irregular areas, from $\mathrm{cm}^{2}$ to $\mathrm{m}^{2}$. 2. It is particularly suited to the fabrication of heterojunctions simply through a change in the deposition electrolyte. The disadvantages of electrodeposition are:1.Not applicable for the insulating substrate. 2. Poor thickness uniformity on complex components

\subsection{Successive ionic layer adsorption and reaction method (SILAR)}

Thin-film deposition by this method has recently attracted attention among many researchers because the method offers many advantages over the more established synthetic routes to 
obtain semiconductor materials. SILAR is based on the immersion of the substrate into separately placed cationic and anionic precursors. Fig. 3 shows the graphical representation of the SILAR technique. The growth model is the basic difference between CBD and SILAR. In CBD all the precursors are present at the same time in the reaction vessel, whereas in the SILAR, the substrate is treated separately with each precursor and rinsing separates these treatments. There are different preparative parameters of the SILAR method, such as the composition of precursor, $\mathrm{pH}$ of the cationic and anionic precursor solutions, reaction and rinsing time, deposition temperature, dip cycle, etc. These parameters were optimized to prepare p-type, uniform, pin-hole free, and adherent CISe thin films with maximum thickness. ${ }^{[149]}$ The SILAR is based on a sequential reaction at the substrate surface. Rinsing follows each reaction, which enables heterogeneous reaction between the solid phase and solvated ions in the solution.

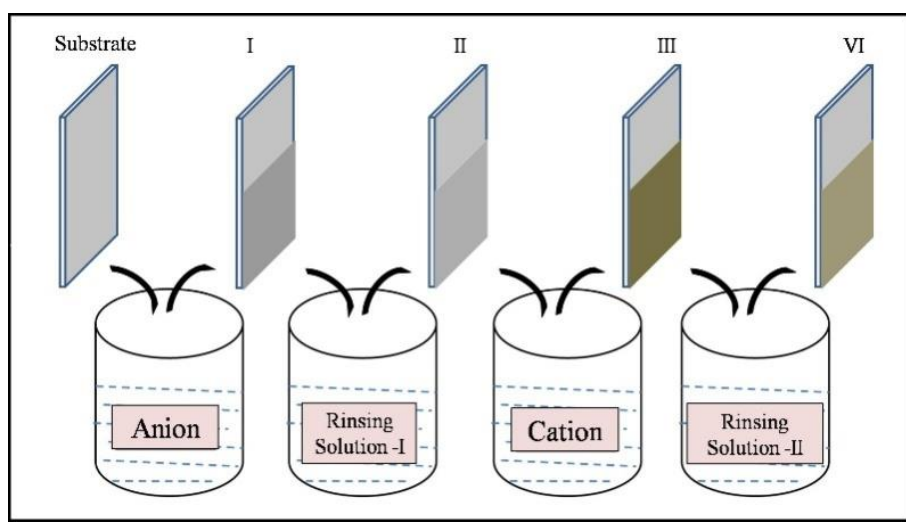

Fig. 3. SILAR synthesis system schematics.

This method is mainly based on the adsorption and reaction of the ions from the solution on the substrate. In addition to this rinsing, the substrate is done between every immersion with deionized water to avoid homogeneous precipitation in the solution. The adsorption takes place between ions and the surface of the substrates due to Vander Waal forces of attraction. Rinsing time is selected such that there is no formation of precipitation in the cationic and anionic precursor. The thickness of the film is controlled directly by the number of deposition cycle and deposition temperature. When the substrate is immersed in the copper and indium containing solution with a complexing agent, then $\mathrm{Cu}^{2+}$ and $\mathrm{In}^{3+}$ ions are adsorbed on the surface of the substrate. TEA is the most popular complexing agent. ${ }^{[9]}$ After immersion of the substrate in a solution containing $\mathrm{Se}^{2-}$ ions, reaction corresponding to CISe takes place.

$$
\mathrm{Cu}^{+}+\mathrm{In}^{3+}+\mathrm{Se}^{2-} \rightarrow \text { CISe }
$$

In general, the following sequence of SILAR technique gives good quality thin films.

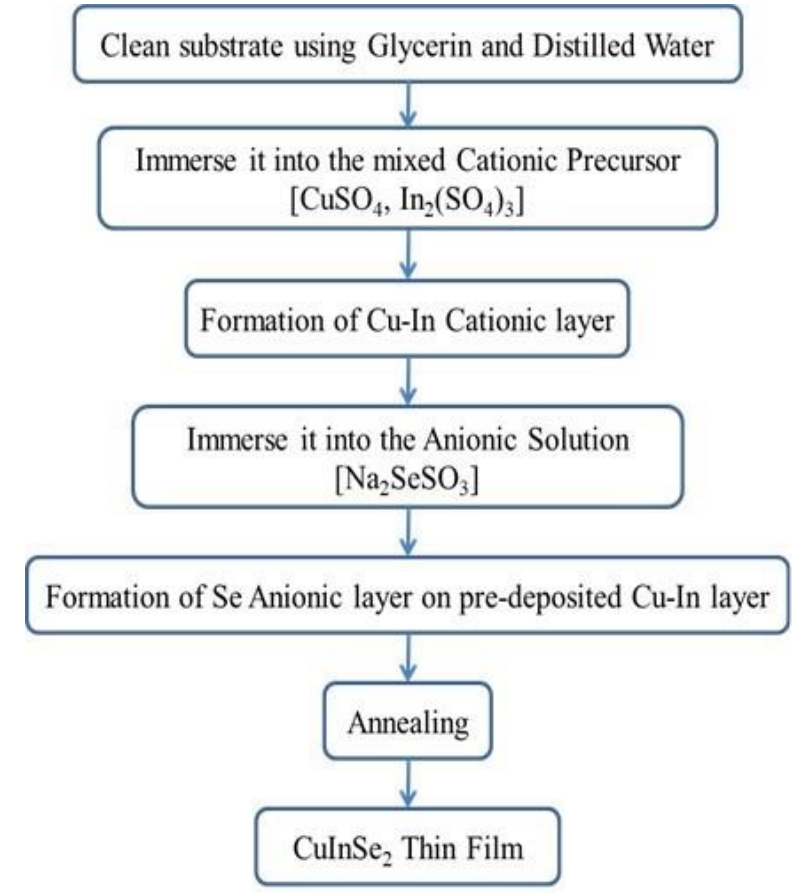

By repeating these cycles, a thin layer of the material can be grown. The graphical sequence gives the proper idea of the formation of a good quality thin film by using the SILAR method. The flow chart gives the exact steps of the deposition of CISe by using SILAR methods.

Pathan et al. firstly used M-CBD to prepare CISe film at room temperature, studied the structural, morphological, and electrical properties of the film. ${ }^{[150]}$ Recently, most of the researchers reported the effect of different cationic precursor solutions on the formation of CISe thin films by this method. The film thickness increases with an increase in concentration and deposition cycle. SEM images of such films were found to be smooth and uniform. Yang et al. prepared CISe thin films by using this technique with different deposition temperatures $\left(\mathrm{T}_{\mathrm{d}}\right) .{ }^{[151]}$ The solution bath contains $\mathrm{CuCl}_{2}, \mathrm{InCl}_{3}, \mathrm{TEAH}_{3}$, citrate, $\mathrm{Na}_{2} \mathrm{SeSO}_{3}, \mathrm{HCl}$, and $\mathrm{NH}_{4} \mathrm{OH}$. The deposition of CISe films was carried out at different temperatures such as 30,50 , 70 , and $90{ }^{\circ} \mathrm{C}$, respectively.To achieve the required thickness, all stages are repeated from 20 to 100 times. The surface roughness of CISe films depends on dip cycle times and deposition temperature. The morphology the film varys with increasing temperature. The thickness of the films increases from $180 \mathrm{~nm}$ at $30^{\circ} \mathrm{C}$ to $1000 \mathrm{~nm}$ at $90^{\circ} \mathrm{C}$, and this implys that the growth rate of the film is varied with $\mathrm{T}_{\mathrm{d}}$. They also explained the variation of the morphology of the film by increasing the dipping cycle. At 20 dip cycles, the surface of the film is very smooth and uniform. At 40 dip cycles, grain size becomes larger. With further increasing the dip cycle, isolated islands increase on the film surface and the area of these islands successively increases (dip cycle $=60,80,100$, $\mathrm{T}_{\mathrm{d}}=30^{\circ} \mathrm{C}$ ). This non-uniform growth is due to the inhomogeneous nucleation growth. 
Table 3. Preparative parameters for the deposition of CISe thin films using SILAR method.

\begin{tabular}{|c|c|c|c|c|}
\hline $\begin{array}{l}\text { Sr. } \\
\text { No. }\end{array}$ & Precursors & $\begin{array}{l}\text { Substrate } \\
\text { Temp. }\left({ }^{\circ} \mathrm{C}\right)\end{array}$ & Results & Reference \\
\hline 1 & $\begin{array}{l}0.12 \mathrm{M} \mathrm{CuSO}_{4}, 0.08 \mathrm{In}_{2}\left(\mathrm{SO}_{4}\right)_{3} \\
0.05 \mathrm{M} \mathrm{Na}_{2} \mathrm{SeSO}_{3} \text { TEA. }\end{array}$ & $\begin{array}{l}\mathrm{G} \\
27\end{array}$ & The electrical resistivity $10^{2}-10^{3} \Omega \mathrm{cm}$ & {$[151]$} \\
\hline 2 & 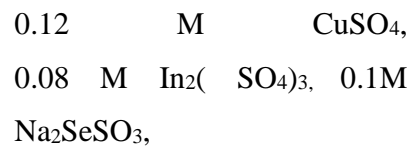 & $\begin{array}{c}\text { G \& FTO } \\
27\end{array}$ & $\begin{array}{l}\text { The XRD \& HRTEM studies showed the nanocrystalline } \\
\text { CISe. }\end{array}$ & [152] \\
\hline 3 & $\begin{array}{l}\mathrm{CuCl}_{2.2 \mathrm{H}_{2} \mathrm{O},} \quad \mathrm{InCl}_{3.4 \mathrm{H}_{2} \mathrm{O},} \\
\text { TEA, } \\
\mathrm{Na}_{3} \mathrm{C}_{6} \mathrm{H}_{5} \mathrm{O}_{7}, \\
(\mathrm{pH}=8)\end{array}$ & $\begin{array}{l}\mathrm{G} \\
30-90\end{array}$ & $\begin{array}{l}\text { Accelerated growth rate by deposition time could reduce } \\
\text { the dip cycle time for required film thickness, which } \\
\text { improved the quality of film morphology }\end{array}$ & [158] \\
\hline 4 & $\begin{array}{l}\mathrm{CuCl}_{3}, \mathrm{InCl}_{3}, \mathrm{TEA}, \mathrm{Na}_{2} \mathrm{SeSO}_{3} \\
\quad \mathrm{Na}_{3} \mathrm{C}_{6} \mathrm{H}_{5} \mathrm{O}_{7}\end{array}$ & $\begin{array}{l}\mathrm{G} \\
70\end{array}$ & $\begin{array}{l}\text { The annealed samples show crystallinity.SEM results } \\
\text { in shows smooth surface }\end{array}$ & [159] \\
\hline 5 & $\begin{array}{l}\mathrm{CuCl}_{2}, \mathrm{InCl}_{3}, \mathrm{TEAH}_{3}, \mathrm{CitNa}, \\
\mathrm{HCl}, \mathrm{NH}_{4} \mathrm{OH}, \mathrm{Na}_{2} \mathrm{SeSO}_{3}, \mathrm{CH}_{3}- \\
\left(\mathrm{CH}_{2}\right)_{11,-\mathrm{C}_{6} \mathrm{H}_{4}-\mathrm{SO}_{3} \mathrm{Na} .}\end{array}$ & $\begin{array}{l}\text { G } \\
\text { R.T. }\end{array}$ & $\begin{array}{l}\text { The XRD displayed the main reflection peaks at } 26.7^{0} \text {, } \\
44.3^{0}, 52.4^{0} \text { have corresponded to the CISe planes }(112) \text {, } \\
(220) /(204) \text {, and }(312) /(116) \text { resp. The } \mathrm{Cu} \text {, In and Se } \\
\text { element analysis of rod crystals detected by EDS is } \\
23.81 \%, 22.72 \% \text {, and } 53.47 \% \text { resp, close to CISe } \\
\text { stoichiometry of } 1: 1: 2\end{array}$ & [157] \\
\hline
\end{tabular}

When $\mathrm{T}_{\mathrm{d}}=70{ }^{\circ} \mathrm{C}$, the morphology of CISe film has a similar trend, but isolated islands seem at fewer times of dip cycle. Furthermore, the grain size of these films prepared at $70^{\circ} \mathrm{C}$ is more than $30^{\circ} \mathrm{C}$ under the same dip cycle times.

Pathan and Lokhande et al. prepared CISe thin films by using the M-CBD technique at room temperature. ${ }^{[152]} \mathrm{A}$ solution contained copper sulfate, indium sulfate, sodium sulfite, selenium pellets, and tartaric acid. The concentration of anionic precursor $\left(\mathrm{Na}_{2} \mathrm{SeO}_{3}\right)$ was arbitrarily maintained constant at $0.05 \mathrm{M}$ with $\mathrm{pH}-12$. They prepared CISe film by using 80 deposition cycles. From highermagnified SEM image and AFM micrograph, small isolated grains with spongy surface were reported for the $\mathrm{Cu}$ rich films. The surface is well covered with CISe. At the right-hand side of the image, the intensity strip indicates the height of the surface grain along the Z-axis. The grain boundaries are seen. Continuous arrangements ofclosely packed grains observed the spherical grains are visible, which indicates the 3-D growth of the film. Now there are several reports about CISe film with rod/wires with a controllable composition. Mostly, these rods/wires were prepared by solvothermal or vapor-liquid-solid method at a very high temperature using extremely high toxic materials. ${ }^{[153-156]}$

Yang et al. prepared a CISe film using sodium dodecylbenzene sulphonate (SDBS) as a directing agent by SILAR. ${ }^{[157]}$ The solution contained anionic precursor 0.06 $\mathrm{mol} / \mathrm{L} \mathrm{Na}_{2} \mathrm{SeSO}_{3}$ solution with $8 \mathrm{pH}$ and cationic precursor $\mathrm{CuCl}_{2}, \mathrm{TEAH}_{3}, \mathrm{InCl}_{3}$, sodium citrate (CitNa), $\mathrm{HCl}, \mathrm{NH}_{4} \mathrm{OH}$, and SDBS. Rod crystals appeared on the surface of the CISe film after adding SDBS to the solution. SDBS was added into a cationic precursor solution from 0 to $0.01 \mathrm{~mol} / \mathrm{L}$. This process was carried out at $70{ }^{\circ} \mathrm{C}$. Without SDBS, the morphologies of the annealed CISe film were clear and consisted of granular grains with slightly agglomerate compared with the as-grown films. However, with SDBS, the rod-like agglomerations, stacked by $\mathrm{CuSe}$ and $\mathrm{In}_{2} \mathrm{Se}_{3}$, appeared on the surface of the film. After annealing, the loose structure of CISe film could provide high vapor pressure for solid-vapor-solid mass transfer growth of rod-type crystals. The effect of SDBS on rod crystals growth was studied by changing the amount of SDBS. With the increase of SDBS, the length of CISe rod crystals was increased, but the diameter of the rod changed slightly except several dumpy rods. At low SDBS contents, a few rods of crystals were formed, but as the SDBS content increases, the size of the rod crystal gets an increase. While SDBS increased to $0.01 \mathrm{~mol} / \mathrm{L}$, the length of the rod crystal exceeded up to $5 \mu \mathrm{m}$. The preparative parameters of the SILAR method as shown in Table 3.

Advantages of the SILAR methodare detailed as: 1. SILAR does not require a target, nor does it require a vacuum at any stage of the process. 2 . The deposition rate and the thickness of the film can be easily controlled over a wide range by changing the deposition cycle. Disadvantages of the SILAR method asre: 1. Expensive autoclaves are needed.2. Safety issues during the reaction process, and impossibility of observing the reaction process. 


\subsection{Spray pyrolysis (SP)}

This technique has been one of the major techniques being used for the deposition of thin films of a wide variety of materials for the past three decades. This technique has also been successfully employed for the formation of superconducting oxide films. In this method, the properties of the thin films depend on the anion to cation ratio, spray rate, substrate temperature, carrier gas, droplet size, spray time, the concentration of the solution, spray gun nozzle to substrate distance, etc. The main advantages of this method are: 1) It neither requires high-quality substrate nor vacuum at any stage. 2) There are no virtual restrictions on the substrate material, dimension, or surface profile. 3) The deposition rate and thickness of the film are easily controllable over a wide range by changing the spray parameter and 4) Operates at moderate temperatures $\left(100-500^{\circ} \mathrm{C}\right)$.

Fig. 4 shows the graphical representation of the spray pyrolysis technique. The spray gun sprays the cationic and anionic precursor solution on a heated glass substrate. The deposited film property shows variations with the change of $\mathrm{pH}$ value of the spray solution. Excellent controllability of the film composition can also be achieved by changing the spray solution composition. It is known that the composition ratio $\mathrm{Cu} / \mathrm{In}$ affects not only the electrical properties but also the structural ones. It was observed that $\mathrm{Cu}$ rich films exhibit chalcopyrite structure with the appearance of the characteristic XRD lines corresponding to 101, 211, and 301 planesirrespective of the $\mathrm{pH}$ value. The In-rich films deposited at $300{ }^{\circ} \mathrm{C}$ exhibit no XRD lines. ${ }^{[160]}$ However, at $360^{\circ} \mathrm{C}$, both In and $\mathrm{Cu}$ rich films were found to exhibit the chalcopyrite structure, independent of $\mathrm{pH}$. Terasako et al. prepared In rich CISe polycrystalline thin films by this method. ${ }^{[2]}$ The spray solution containing an aqueous ethanol solution of $\mathrm{CuCl}_{2}$, $\mathrm{InCl}_{3}$, and $\mathrm{N}, \mathrm{N}$, dimethyl selenourea (DMSeU). The substrate temperature was $360{ }^{\circ} \mathrm{C}$. The $\mathrm{In} /(\mathrm{Cu}+\mathrm{In})$ ratio got varied from 0.5 to 0.83 . The $\mathrm{pH}$ value was adjusted up to 3.5 by adding $\mathrm{NH}_{4} \mathrm{OH}$.The SEM images were observed for the CISe films with various in $/(\mathrm{Cu}+\mathrm{In})$ ratios grown at $360^{\circ} \mathrm{C}$. The diameter of the round grains for the films with an $\mathrm{In} /(\mathrm{Cu}+\mathrm{In})$ ratio of $0.55,0.60,0.67$ was observed in the range of $0.1-0.3,0.3-0.4$, and $0.3-0.5 \mu \mathrm{m}$, respectively. The round and platelet grains observed on the surface of the film with the $\mathrm{In} /(\mathrm{Cu}+\mathrm{In})$ ratio were 0.70 . It can be easily found that the surface morphologies of the films with in $/(\mathrm{Cu}+\mathrm{In} \geq 0.72$ differ from those of the films with in/(Cu+In $) \leq 0.70$. The composition of the CISe film is plotted in a ternary composition plane.$^{[161]}$ The plots are on the tie line of the $\mathrm{Cu}_{2} \mathrm{Se}_{-} \mathrm{In}_{2} \mathrm{Se}_{3}$ pseudobinary system, which indicates that the valance stoichiometry is preserved. If the films contain the $\operatorname{In}_{2} \mathrm{O}_{3}$ phase, plots should be on the left side of the $\mathrm{Cu}_{2} \mathrm{Se}_{2}-\mathrm{In}_{2} \mathrm{Se}_{3}$ tie line. The preparative parameters of the SP method are shown in Table 4.

Advantages of spray pyrolysis are: spherical morphology, narrow particle size distribution, compositional homogeneity, and high controllability of composition of the obtained products. Disadvantages ofspray pyrolysis are not easy to scale-up (yield is very low), (2) oxidation of sulfides when processed in air atmosphere is possible; (3) there are difficulties with determining the growth temperature.

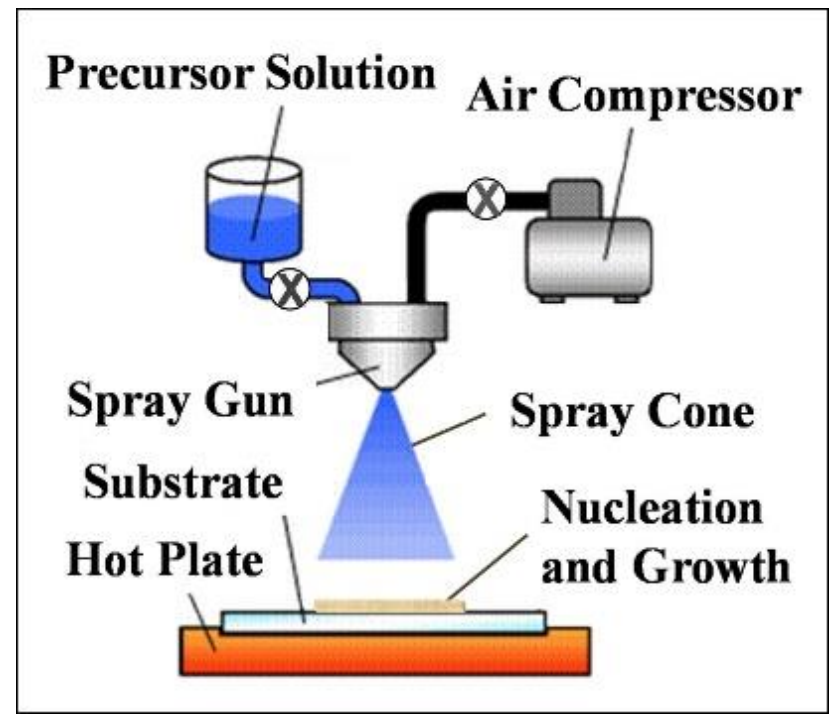

Fig. 4 Spray pyrolysis deposition system schematics.

Table 4. Preparative parameters for the deposition of CISe thin films using the spray pyrolysis technique.

\begin{tabular}{|c|c|c|c|c|c|}
\hline Sr.No. & Precursors & $\begin{array}{l}\text { Substrate } \\
\text { Temp. }\left({ }^{\circ} \mathrm{C}\right)\end{array}$ & $\&$ & Results & Ref. \\
\hline 1. & $\begin{array}{l}\mathrm{CuCl}_{2}, \mathrm{InCl}_{2} \\
\mathrm{~N}, \mathrm{~N}, \mathrm{DMSeU}\end{array}$ & $\begin{array}{c}\mathrm{G} \\
300-350\end{array}$ & & $\begin{array}{l}\text { Below } 250^{\circ} \mathrm{C} \text {, the peaks decreased in size, whereas above } 400^{\circ} \mathrm{C} \text {, } \\
\text { the second phase was generated shown in XRD. Annealing at } \\
500^{\circ} \mathrm{C} \text { shows crystalline nature }\end{array}$ & [161] \\
\hline 2. & $\begin{array}{l}\mathrm{CuCl}_{2}, \mathrm{InCl}_{3} \\
\mathrm{~N}, \mathrm{~N}, \mathrm{DMSeU}, \mathrm{NH}_{4} \mathrm{OH} . \\
(\mathrm{pH} \sim 1.9-4.0)\end{array}$ & $\begin{array}{c}\mathrm{G} \\
300-360\end{array}$ & & $\begin{array}{l}\text { bandgap }\left(\mathrm{E}_{\mathrm{g}}\right) \text { of } 1.02 \mathrm{eV} \text {. } \\
\text { Film resistivity } 10^{-2} \text { to } 10^{5} \Omega \mathrm{cm}^{-1} \\
\text { In SEM, porous morphology with rod-like grains }\end{array}$ & [162] \\
\hline 3 & $\begin{array}{l}\mathrm{CuCl}, \mathrm{InCl}_{3} \\
\mathrm{CSe}\left(\mathrm{NH}_{2}\right)\end{array}$ & $\begin{array}{l}\mathrm{SnO}_{2} \\
350\end{array}$ & & The best PEC cell showed a $6.22 \%$ conversion efficiency & [122] \\
\hline 4. & $\begin{array}{l}\mathrm{CuCl}_{2}, \mathrm{InCl}_{3} \\
\mathrm{~N}, \mathrm{~N}, \mathrm{DMSeU} . \\
(\mathrm{pH} \sim 3.5)\end{array}$ & $\underset{360-400}{G}$ & & The $\mathrm{E}_{\mathrm{g}}$ value increased from 1.22 to $1.36 \mathrm{eV}$ & {$[163]$} \\
\hline 5. & $\begin{array}{l}\mathrm{CuCl}_{3}, \mathrm{TEA} \\
\mathrm{InCl}_{3}, \mathrm{Na}_{3} \mathrm{C}_{6} \mathrm{H}_{5} \mathrm{O}_{7} \\
\mathrm{Na}_{2} \mathrm{SeSO}_{3}\end{array}$ & $\begin{array}{l}G \\
70\end{array}$ & & $\begin{array}{l}\text { The XRD, XPS, and SEM results showed that it was crystallized, } \\
\text { smoothly, and distinctly particular. }\end{array}$ & {$[117]$} \\
\hline
\end{tabular}


Table 5. Preparative parameters for the deposition of CISe thin films using a hydrothermal technique.

\begin{tabular}{|c|c|c|c|c|}
\hline $\begin{array}{l}\text { Sr. } \\
\text { No. }\end{array}$ & Precursors & Temp. $\left({ }^{\circ} \mathrm{C}\right)$ & Results & Ref. \\
\hline 1 & $\begin{array}{l}\text { Acetic acid, Copper powder, } \\
\text { Indium powderand selenium } \\
\text { powder }\end{array}$ & 200 & SEM images showed particle size between $\mu \mathrm{m}$ to $\mathrm{nm}$. & [165] \\
\hline 2 & $\begin{array}{l}\text { copper (II) chloride, indium (In), } \\
\text { sulfur }(\mathrm{S}) \text {, selenium }(\mathrm{Se}) \\
\text { deionized water }\end{array}$ & 180 & $\begin{array}{l}\text { XRD pattern chalcopyrite (tetragonal) structure of synthesized samples. } \\
\text { SEMand TEM analyses show that samples were composed of cubes } \\
\text { with the size of nanometers. }\end{array}$ & [166] \\
\hline 3 & $\mathrm{CuCl}_{2} \cdot 2 \mathrm{H}_{2} \mathrm{O}, \mathrm{InCl}_{3}$, and $\mathrm{SeO}_{2}$ & $\begin{array}{l}160 \\
180 \\
200\end{array}$ & $\begin{array}{l}\text { The XRD peak corresponding to }(112),(204) \text {, and (312) crystal planes, } \\
\text { respectively. The powders consist of irregular spherical grains with } \\
0.2 \sim 0.5 \mu \mathrm{m} \text { in diameter }\end{array}$ & [167] \\
\hline 4 & $\begin{array}{l}\text { Cupric chloride, indium chloride, } \\
\text { sodium selenite, } \\
\text { ethylenediamine, deionized } \\
\text { water. }\end{array}$ & 150 & $\begin{array}{l}\text { The crystallinity was found to be higher with a } 10 \text { mol ratio of the } \\
\text { capping agent. While the optical absorption and emission are concerned } \\
\text { the } 10 \text { EA has higher absorption and emission intensity followed by the } \\
10 \text { EW. }\end{array}$ & [168] \\
\hline 5 & $\begin{array}{l}\text { Copper foils, indium chloride, } \\
\text { triethanolamine, sodium } \\
\text { hydroxide }\end{array}$ & 80 & $\begin{array}{l}\text { The crystallinity and density of the as-synthesized CISe films were } \\
\text { improved via increasing the selenization temperatures and prolonging } \\
\text { the hydrothermal duration. } \mathrm{Se}^{2-} \text { ions react with copper foils to form the } \\
\mathrm{Cu}_{2-\mathrm{x}} \mathrm{Se} \text { phase at the beginning of the reaction. Indiumions adhere to the } \\
\mathrm{Cu}_{2-\mathrm{x}} \mathrm{Se} \text { surface, owing to the chelation of triethanolamine. } \mathrm{In}^{3+} \text { and } \mathrm{Se}^{2-} \\
\text { ions then reaction } \mathrm{Cu}_{2-\mathrm{x}} \mathrm{Se} \text { to form the } \mathrm{In}_{2} \mathrm{Se}_{3} \text { phase. }\end{array}$ & [169] \\
\hline
\end{tabular}

\subsection{Hydrothermal Method}

The hydrothermal method is widely used to prepare nanostructural materials because of its simplicity, high efficiency, and low cost. It is the most commonly used method for the preparation of nanomaterials. The hydrothermal technique is becoming one of the most important tools for advanced materials processing, particularly owing to its advantages in the processing of nanostructural materials for a wide variety of technological applications such as electronics, optoelectronics, catalysis, ceramics, magnetic data storage, biomedical, biophotonics, etc. Hydrothermal can be defined as 'hydros' meaning water and 'thermos' meaning heat. Several methods have been reported on the deposition of $\mathrm{CuInSe}_{2}$ thin films and nanoparticles such as chemical bath deposition, magnetron sputtering, flash evaporation, spray pyrolysis as well as thermolysis, photolysis, microwave synthesis, microwave irradiation, sol-gel, wet chemical, solvothermal and hydrothermal methods. However, the above approaches required complicated facilities, high temperatures and some of them use toxic reagents like organometallic compounds and hydrogen sulfide $\left(\mathrm{H}_{2} \mathrm{~S}\right)$. To avoid these drawbacks, hydrothermal and solvothermal methods have been widely studied. This method is also particularly suitable for the growth of large good-quality crystals while maintaining control over their composition. The preparative parameters of the SP method are shown in Table 5. Disadvantages of the hydrothermal methodare: (1) the need of expensive autoclaves; (2) safety issues during the reaction process; and (3) impossibility of observing the reaction process.

\section{Properties of CISe thin films 3.1 Structural}

The process of XRD methods observes the crystallographic features of CISe films. This characterization technique is beneficial to determine various properties of the thin films like crystal structure, crystalline orientation, grain size, lattice parameters, lattice strain, and stress, etc. In comparison of observed inter-planar distance and standard value, CISefilm has a chalcopyrite tetragonal structure. But some literature shows different values, which are comparable to the secondary phase. It means that thin-film contains some impurities as well as some defects. ${ }^{[8]}$ This information was beneficial for the photovoltaic application. Akl et al. studied the effect of $\mathrm{Cu} / \mathrm{In}$ ratio as well as substrate temperature on the structural properties of the CISe films. ${ }^{[169]}$ The chemical technique was used to prepare polycrystalline CISe films. The XRD pattern of the as-deposited CISe films on a glass substrate at different $\mathrm{Cu} / \mathrm{In}$ ratios shows an additional line at $24.2^{0}$, which is identified for the $\mathrm{Cu}_{2-x} \mathrm{Se}$ phase. The $\mathrm{Cu}_{2-\mathrm{x}} \mathrm{Se}$ phase detected at the $\mathrm{Cu} / \mathrm{In}$ ratio reached 0.96 and more at temperature 548,573 , and $673 \mathrm{~K}$. The phase of $\mathrm{Cu}_{2-\mathrm{x}} \mathrm{Se}$ disappeared at all substrate temperature for ratio less than 0.96. Moreover, the (112), (204), and (312) peaks indicate the single phase of CISe having the tetragonal structure. The chalcopyrite phase was obtained for the prepared films independent of both the substrate temperature and the $\mathrm{Cu} / \mathrm{In}$ ratio. The intensity of the (112) peak gets concerning the $\mathrm{Cu} / \mathrm{In}$ ratio at different substrate temperatures. The profile shape parameter was obtained through a pattern decomposition followed by a Voigt function for size strain separation. Voigt function is based on the integral breadth of lines used to calculate the crystallite size of the investigated sample. The crystallite size calculated with different $\mathrm{Cu} / \mathrm{In}$ ratio at different substrate temperatures results in that the crystallite size gets increased by increasing the $\mathrm{Cu} / \mathrm{In}$ ratio and decreased by increasing the substrate 
temperature. This means that the growth under $\mathrm{Cu}$ rich conditions seems favorable to the obtainment of large crystallite size. The behavior of this crystallite size in an indium rich and copper-rich sample was reported in the literature. ${ }^{[170-171]}$ The macro-strain decreases with the raise of either $\mathrm{Cu} / \mathrm{In}$ ratio or the substrate temperature which is expected since the atoms or molecules are ejected from the target source by higher momentum transfer due to its ionic collisions observed.

The microstrains were produced due to more power density events with higher kinetic energy and mobility, which were recombined on the substrate surface. The grain size of the film depends on the composition of the film. The grain size calculated by using the Debye-Scherer relation $(\mathrm{D}=0.9$ $\lambda / \beta \operatorname{Cos} \theta$, where $\beta$ is the full-width half maxima, and $\lambda$ is the wavelength of $\mathrm{CuK}_{\alpha}$ ). Bindu et al. prepared CISe film through a new selenization process. ${ }^{[172]}$ The $\mathrm{Cu}$ rich sample showed maximum grain growth $(180 \AA)$. As the ratio increases, grain size increases and reaches saturation when the ratio is 1.6. In the case of a large ratio, $\mathrm{Cu}$ may reduce the stoichiometry of the films, resulting in reduced grain size. The XRD patterns of the CISe filmswith different $\mathrm{Cu} / \mathrm{In}$ ratiosshow that as the $\mathrm{Cu} / \mathrm{In}$ ratio increases, the intensity of all the peaks increases from curve $\mathrm{c}$ to $\mathrm{f}$, respectively. For film 1.8 , the peak intensity decreases, because excess $\mathrm{Cu}$ reduces the stoichiometry of the film. The FWHM value of the film corresponds to the (112) planes of the respective films obtained from the XRD.

In the SP technique, the crystal structure of the CISe film depends on the $\mathrm{Cu} / \mathrm{In}$ ratio, substrate temperature, and $\mathrm{pH}$ of the solution. Shirakat et al. prepared the CISe films on glass substrate from the ethanol by chemical SP. ${ }^{[161]}$ Good chalcopyrite CISe films with large grains have been grown using a neutralized spray solution $(\mathrm{pH}=4)$ at the growth temperature of $360^{\circ} \mathrm{C}$. On the other hand, low values of Ts, $\mathrm{pH}$, and $\mathrm{Cu} / \mathrm{In}$ led to the production of sphalerite films Ranges of $\mathrm{Cu} / \mathrm{In}$ and $\mathrm{T}_{\mathrm{s}}$ for the production of the chalcopyrite and the sphalerite phase are summarized for $\mathrm{pH}$ values 1.9 and 4.0. From this graph, it can be said that the $\mathrm{Cu}$ rich CISe films tend to have the chalcopyrite structure, whereas the In rich ones tend to have a sphalerite structure containing the $\operatorname{In}_{2} \mathrm{Se}_{3}$ phase. To form the chalcopyrite structure, additional energy is required to order the atoms from the disordered sphalerite form. This is the reason why the activation energy for the chalcopyrite phase formation $\left(\mathrm{E}_{\mathrm{c}}\right)$ is larger than that for the sphalerite one $\left(E_{s}\right)$. Therefore, the energy gained due to high $\mathrm{T}_{\mathrm{s}}$ may enhance the production of the chalcopyrite-type film. Wellings et al. deposited CISe film by using ED techniques. CISe film prepared from ethylene glycol at $150{ }^{\circ} \mathrm{C}$. ${ }^{[120]}$ The following graph shows the composition study of the layer by using EDAX techniques. Identified characteristic peaks of $\mathrm{Cu}$ and $\mathrm{Se}$ with small in peak also present for the layer deposited at $-0.080 \mathrm{~V}$ vs Se. The EDAX of the film deposited at -0.95 and $-1.00 \mathrm{~V}$ vs Se were the same, indicating that $\mathrm{Cu}$, In and Se were present in the bulk. Yang et al. prepared case films by alternating the double-potentiostatic ED(DPED) method using nearly neutral electrolytes with sodium citrate complex. ${ }^{[173]}$ Voltammograms of $\mathrm{CuCl}_{2}, \mathrm{InCl}_{3}, \mathrm{SeO}_{2}$ individual and mixed solutions with $\mathrm{CitNa}$ - complexing agents were measured. The solution bath contained $2 \mathrm{mM} \mathrm{CuCl}_{2}, 0.6 \mathrm{mM}$ $\mathrm{InCl}_{3}, 4 \mathrm{mM} \mathrm{SeO}_{2}$, and $15 \mathrm{mM}$ sodium citrate, and the $\mathrm{pH}$ of the electrolyte solution was adjusted by $\mathrm{NaOH}$ and $\mathrm{HCl}$. This is a three-electrode system, in which indium tin oxide coated glass (ITO) was used as working electrodes, a large area Pt foil acted as a counter electrode, and $\mathrm{Ag} / \mathrm{AgCl}_{\text {sat }}(+222 \mathrm{mV} / \mathrm{NHE})$ as a reference electrode. According to the result of voltammograms, the double potentiostatic parameter was selected as $V_{1}=-800 \mathrm{mV}$ for $t_{1}=30 \mathrm{~s}$ and $\mathrm{V}_{2}=-1400 \mathrm{mV}$ for $\mathrm{t}_{2}=60 \mathrm{~s}$, for 5 cycles. As a contrast, some films were also prepared by the single potentiostatic condition at -800 and $1400 \mathrm{mV}$ resp.

FromXRD, clear characteristics peaks of the ITO substrate are observed. When the film was deposited by the single potentiostatic ED (SPSED) method at $-800 \mathrm{mV}$, only $\mathrm{Cu}_{2} \mathrm{O}$ and little $\mathrm{CuSe}$ phase appear after annealing and at $-1400 \mathrm{mV}$, InSe and a small amount $\mathrm{In}_{2} \mathrm{Se}_{3}$ phase occurs but no $\mathrm{Cu}$ containing phase appears. However, (112) peak at $26.6^{0},(204,220)$ peaks at $44.2^{0}$, and $(116,312)$ peaks at $52.3^{\circ}$ of chalcopyrite CISe phase can be observed after annealing by DPED. The diffraction peaks of CuIn alloy and metal indium are observed without any selenium containing crystal substance. These detected results illuminate the advantages of the DPED method, in which the reduction of $\mathrm{Cu}^{2+}$ to $\mathrm{Cu}^{+}$at one potential point of $-800 \mathrm{mV}$ as well as of CuIn alloy in the as-deposited film is responsible for the formation of CISe chalcopyrite. The high resolution XPS spectra in $\mathrm{Cu} 2 \mathrm{p} 3 / 2, \mathrm{In} 3 \mathrm{~d} 5 / 2$ and $\mathrm{Se} 3 \mathrm{~d} 5 / 2$ regions are observed. The binding energy $(\mathrm{BE})$ of $\mathrm{Cu} 2 \mathrm{p} 3 / 2$, In $3 \mathrm{~d} 5 / 2$ and $\mathrm{Se} 3 \mathrm{~d} 5 / 2$ is $932.7,444.6$, and $54.8 \mathrm{eV}$ respectivley after annealing. The corresponding BE values for the asdeposited films are 932.1, 444.3, and $55.1 \mathrm{eV}$, respectively. The BE values of $\mathrm{Cu} 2 \mathrm{p} 3 / 2$ and $\mathrm{In} 3 \mathrm{~d} 5 / 2$ for the as-deposited film are slightly less than that of the annealed film, due to the formation of CuIn alloy in the film. But for $\mathrm{Se} 3 \mathrm{~d} 5 / 2$, the $\mathrm{BE}$ value is different from that of the annealed film. There is a second peak (59.3) appearing on the Se3d5/2 high-resolution curve, which corresponds to the $\mathrm{BE}$ value of $\mathrm{SeO}_{2}$. It means that $\mathrm{SeO}_{2}$ may be deposited on film during the DPED process, which is permitted to be eliminated by de-oxidation of $\mathrm{SeO}_{2}$ in the period of the annealing in the Argonatmosphere.The complexing agent is used to improve the crystallinity of the film. Yamaguchiet al. electrodepositedCISefilm by using triethanolamine (TEA) as the complexing agent. ${ }^{[174]}$ The effect of concentration of TEA on the formation of the CISe film, the XRD patterns of CISe films deposited with $0.05,0.1$, and 1.0 $\mathrm{M}$ of TEA were exhibited.From the XRD patterns, it was found that the crystalline signals of the CISe were less strong, especially the preferred orientation in the (112) plane of the chalcopyrite structure, as the concentration of TEA exceeded $0.1 \mathrm{M}$. It is believed that the complexing reaction was complete with a high concentration of complexing agents and therefore hindered the deposition of CISe film. The SEM 
images bring to a comparison of the surface grains from the deposited films under different potentials. In the case of -0.6 $\mathrm{V}$ vs $\mathrm{Ag} / \mathrm{AgCl}$ in the multinuclear, cauliflower-like grains of the crystalline structure of CISe are observed. The structural properties of CISe film also depend on the $\mathrm{pH}$ of the solution. Sense et al. discussed the quality of the electrodeposited films. The CISe film depended on the presence of $\mathrm{pH}$ buffer in the bath. ${ }^{[175]}$ The XRD patterns were measured for the as-deposited samples from two types of baths. CISe films deposited from non-pH buffered baths show pronounced (112) orientation, while films exhibiting more random orientation were obtained from $\mathrm{pH}$ buffered paths. The patterns of both the samples show weak and broad peaks characteristics of CISe chalcopyrite phase, but with a high degree of amorphous or microcrystalline phase. One can note that when grown from a non $\mathrm{pH}$ buffered solution, the films appear to grow with some degree of (112) orientation when compared to the XRD pattern of the CISe film deposited from a pH buffered bath. Terasako et al. studied the structural properties of CISe films, which were deposited by the SP technique. ${ }^{[2]}$ For the XRD patterns of the CISe films with different $\mathrm{In} /(\mathrm{Cu}+\mathrm{In})$ ratios grown at $\mathrm{T}_{\mathrm{s}}=$ $360{ }^{\circ} \mathrm{C}$, all the films showed the 112 diffraction peaks. When the $\mathrm{In} /(\mathrm{Cu}+\mathrm{In})$ ratio increases from 0.54 to 0.78 , (112) XRD peak shifts continuously from $26.63^{0}$ to $26.93^{\circ}$. The weak XRD diffraction peaks (101), (211), (105)/ (213), (301), (417)/ (217) and (501) are unique to the chalcopyrite structure observed at the film with $\mathrm{In} /(\mathrm{Cu}+\mathrm{In})$ ratio at 0.5 . The XRD diffraction peaks (301), (417)/ (217) and (501) peaks disappear for the ratio of 0.60 . For more than 0.60 ratio, a diffraction peak due to $\operatorname{In}_{2} \mathrm{Se}_{3}(110)$ can be observed. The lattice constant was calculated from the $2 \theta$ values of (112) and (312) diffraction peaks. The lattice constant a and c decreases with increasing the ratio. The lattice constant changes linearly with increasing the $\mathrm{In} /(\mathrm{Cu}+\mathrm{In})$ ratio. Therefore, the lattice constant along the axis obeys Vegard's law. Frontini et al.prepared CISe films on $\mathrm{TiO}_{2}$ substrates in citrate containing electrolytes by using techniques. ${ }^{[146]}$ In this paper, CISe deposited on $\mathrm{TCO} / \mathrm{d}-\mathrm{TiO}_{2}$ and $\mathrm{TiO}_{2} / \mathrm{nc}-\mathrm{TiO}_{2}$ by ED at $6 \mathrm{pH}$ value.A uniform deposition with compact surface and a multinuclei cauliflower shape was observed.The stoichiometric CISe sample was used as a good absorber material for highly efficient solar cells. ${ }^{[176]}$ Dharmadasa et al. investigated the stoichiometric change of the sample near the surface region and confirmed the type of electronic conduction of the sample ${ }^{[121]}$ Three separate samples were grown at cathodic voltages of a) 2.03 , b) 2.46 , and c) $2.70 \mathrm{~V}$. The sample rich in $\mathrm{Cu}$ at low cathodic voltages and rich in indium at high cathodic voltages. This quantitative analysis of sputter cleaned surfaces also confirms the composition of the film changes as a function of the growth voltage.

\subsection{Optical properties}

Understanding and modeling of solar cell performance require knowledge of the fundamental optical properties. The optical properties of CISe are beneficial to study the electro- reflectance, optical reflection, and transmission, absorption, luminescence, photovoltage, and photoconductivity, bandgap, etc. The optical spectrum reveals that CISe film has a high absorption coefficient $\left(10^{5} \mathrm{~cm}^{-1}\right)$ and the bandgap energy range from 1.04 to $1.9 \mathrm{eV}$. Huang et al. studied the variations of the optical transmittance spectra of the ED-CISe films deposited on the plastic substrate, measured at room temperature with a UV-Vis spectroscopy in transmission mode. ${ }^{[119]}$ The optical transmittance spectra of as-deposited and annealed films with a step absorption edge at 1028 and $1043 \mathrm{~nm}$ respectively. The energy gap from the intercept of the linear portion of the curve on the horizontal axis is to be 1.195 $\pm 0.005 \mathrm{eV}$ and $1.180 \pm 0.005 \mathrm{eV}$ for the as-deposited and annealed CISe film respectively. The absorbance vs. wavenumber is also estimated from FTIR (Fourier Transform Infra-Red) spectroscopy in the near region $\left(8500-15000 \mathrm{~cm}^{-1}\right)$ through the CISe film. From two traces, the straight-line behavior established the absorbance spectra of as-deposited and annealed films with a step absorption edge at 9680 and $9470 \mathrm{~cm}^{-1}$, respectively. The bandgap energy estimated by this spectrum was found to be $1.200 \pm 0.005$ and $1.174 \pm 0.005 \mathrm{eV}$ for the as-deposited and the annealed film. The bandgap energy of this sample calculated from these two methods is almost equal. Furthermore, there is a change in the energy gap between as-deposited and annealed films. This change might be due to the atom redistribution in CISe film. The value of the absorption coefficient $(\alpha)$ depends on the preparative parameters of the respective methods. In the ED method, the the deposition potentialinfluenced the optical properties. The described absorption coefficient for the sample prepared at different potentials is a function of the photon energy. ${ }^{[133]}$

Bindu et al. prepared CISe thin films through a new selenization process using CBD. ${ }^{[172]}$ The optical band gap of prepared thin films decreased with an increase in $\mathrm{Cu} / \mathrm{In}$ ratio. $\mathrm{Cu}$ rich films showed a high absorption coefficient. The absorption coefficient gets increases with $\mathrm{Cu}$ concentration near the fundamental absorption edge. For $\mathrm{Cu}$ rich film, a significant band tailing effect was observed in the absorption spectrum. From the transmission spectra of the CISe films, Terasako et al. also discussed structural and optical properties of In-rich CISe polycrystalline films, which were prepared by SP technique on a glass substrate in terms of $\mathrm{In} /(\mathrm{Cu}+\mathrm{In})$ ratio. ${ }^{[2]}$ The optical plots of the films with various $\mathrm{In} /(\mathrm{Cu}+\mathrm{In})$ ratios grown at $\mathrm{T}_{\mathrm{s}}=360$ and $400{ }^{\circ} \mathrm{C}$ were obtained. It can be seen that $\mathrm{E}_{\mathrm{g}}$ shifts towards a higher energy side with an increasing $\mathrm{In} /(\mathrm{Cu}+\mathrm{In})$ ratio. i.e. $\mathrm{E}_{\mathrm{g}}$ value increased from 1.22 to $1.36 \mathrm{eV}$ as the $\mathrm{In} /(\mathrm{Cu}+\mathrm{In})$ ratio increased from 0.67 to 0.78 , while it was approximately $1.22 \mathrm{eV}$ for the films with $0.54<\mathrm{In} /(\mathrm{Cu}+\mathrm{In})<0.67$. Photoacoustic $(\mathrm{PA})$ measurement was performed at room temperature under the modulation frequency of $10 \mathrm{~Hz}$. PA spectra of the films with various $\mathrm{In} /(\mathrm{Cu}+\mathrm{In})$ ratios were observed. The arrow on each PA spectrum indicates the $E_{g}$ value determined by the optical absorption measurements. For the film with $(\mathrm{In} / \mathrm{Cu}+\mathrm{In})$ of 0.69 , there is an absorption band with a peak energy of $0.8 \mathrm{eV}$. It can 
seem that the absorption band below the $\mathrm{E}_{\mathrm{g}}$ becomes larger and broader with increasing the $\mathrm{In} /(\mathrm{Cu}+\mathrm{In})$ ratio. The main peak of the absorption band below $\mathrm{E}_{\mathrm{g}}$ shifts towards a higher energy side. For the film with $\mathrm{In} /(\mathrm{Cu}+\mathrm{In})$ of 0.72 , the PA signal below $\mathrm{E}_{\mathrm{g}}$ is extremely larger than above $\mathrm{E}_{\mathrm{g}}$ owing to the interband absorption. These results suggest that the concentration of the point defects and impurities acting as the non-radiative centers becomes larger with an increasing $\mathrm{In} /(\mathrm{Cu}+\mathrm{In})$ ratio. Dharmadasa et al. discussed the variation of the bandgap energy concerning the growth voltage for electrodeposited CISe layers using a two-electrode system. ${ }^{[121]}$

From the optical absorption measurements of some selected sample, the continuous curve was drawn to indicate the variation of the bandgap as the composition was changed to include more indium in the layer. It was evident that the bandgap can be varied from $\sim 1.00$ to $\sim 1.90 \mathrm{eV}$ representing the two extreme values of $\sim 1.00 \pm 0.10 \mathrm{eV}$ (bandgap of CISe) and $\sim 1.90 \mathrm{eV}$ (bandgap of InSe). At higher cathodic potential, the bandgap tends to decrease slowly, mainly due to the inclusion of more indium in deposited layers. These results indicate that these layers can be used very effectively to fabricate multi-layers graded bandgap solar cell structures to absorb a major part of the solar spectrum. Optical spectroscopy was also employed to characterize the nanocrystal. An increase in bandgap energy is one of the characteristics of the size quantization in semiconductor nanoparticle. The Bohr exciton radius of the CISe thin films was found to be $10.7 \mathrm{~nm} .{ }^{[177]}$

\subsection{Electrical properties}

The resistivity of the sample was calculated by two or fourprobe method. In the case of CISe film, the graph nature of log $\rho$ Vs. 1000/T shows that the resistivity decreases with an increase in temperature. After annealing, the resistivity of CISe film decreases because it may be attributed to decreased defects or improvement in particle size. ${ }^{[178]}$ This pattern gives evidence of the semiconductor film. The variation of the logarithm of conductivity with reciprocal of the temperature was observed. The electrical conductivity of the sample at 308 $\mathrm{K}$ was found to be $1.4 \times 10^{-18}(\Omega \mathrm{cm})^{-1}$. The activation energy of the CISe film was calculated by using the slope of the graph. The calculated activation energy was found to be $0.317 \mathrm{eV} \cdot{ }^{[87]}$ Tomoakiet al. showed the activation energy lower than the bandgap energy. ${ }^{[160]}$ This suggests the presence of localized gap states below the conduction band edge. The activation energy for the chalcopyrite- phase formation $\left(E_{c}\right)$ is larger than that for the sphalerite one $\left(E_{s}\right)$. To form the chalcopyrite structures, additional energy is required to order the atoms from the disordered sphalerite phase form. Therefore, the energy gained by the CISe films due to high temperature may enhance the production of the chalcopyrite-type film. CISe films can be either p-type or n-type depending on the $\mathrm{Cu} / \mathrm{In}$ ratio.

The electrical nature of the CISe film also depends on the concentration of the $\mathrm{Se}$ in the precursor solution. It is determined by metal to selenium ratio $(\mathrm{Cu}+\mathrm{In} / \mathrm{Se}) \cdot{ }^{\left[{ }^{[19]}\right.}$ If the ratio was less than unity with excess $\mathrm{Se}$, the film was p-type. When the ratio was greater than unity with Se deficiency, it was n-type, which can be made p-type by annealing. After annealing, the conductivity increases with increasing the Se content. ${ }^{[174]}$ The resistivity of the prepared film depends on the $\mathrm{Cu}: \mathrm{In}$ ratio. The $\mathrm{Cu}$ rich solution shows the low resistivity as compared to the In-rich film. The resistivity of the films with a stoichiometric ratio of 1.5 was found to be a maximum $10^{8}$ ohm.cm (intrinsic region). Shirakawa et al. studied the electrical properties of the CISefilms systematically in terms of substrate temperature (Ts), $\mathrm{pH}$, and $\mathrm{Cu} / \mathrm{In}$ ratio ${ }^{[181]}$

The variation of resistivity of the film also depends on the substrate temperature. The films have been deposited from the un-neutralized $(\mathrm{pH}=1.9)$ and neutralized $(\mathrm{pH}=4.0)$ spray solutions with stoichiometric molar ratio $(\mathrm{Cu} / \mathrm{In}=1.0)$. The film resistivity increases with $T_{s}$ for the un-neutralized solution $(\mathrm{pH}=1.9)$, while it decreases with $\mathrm{T}_{\mathrm{s}}$ for the neutralized solution. The lower resistivity of the films for higher $\mathrm{pH}$ and higher $\mathrm{T}_{\mathrm{s}}$ is considered to be mainly due to the larger hole mobility caused by the improved crystalline quality of the film. The conductivity was found to be p-type. It depends on the excess of $\mathrm{Cu}$ in the solution, which resulted in low resistivity films. ${ }^{[180]}$

Some observation shows that the changes in the electrical resistance are in agreement with composition, and phase evaluation. Saucedo et al.discussed the electrical properties of the CISe film deposited by the ED technique. ${ }^{[124]}$ The average resistance values of the three stages of the CISe film are plotted as a function of the sample thickness.It is explained that in a region I, the resistance increases up to $10 \Omega$ for 250 $\mathrm{nm}$ thickness of the film, then it falls up to $2.3 \Omega$. This is not expected but the actual chemical reaction occurs at $250 \mathrm{~nm}$, which changes the phase and the electrical properties of the complete film. $\mathrm{Cu}$ rich binary compound is responsible for the electrical properties of the layer during the first nucleation stages. In the II-region, the resistance increases uniformly up to $1 \mu \mathrm{m}$, thus indicating that the material added is more resistant than the previous stage. This variation on the slope appears in this region due to the presence of ordered vacancy compound. This measurement of the resistance measured is mainly related to this heavily disordered phase. However, in region III, the material added should be more ordered and thus more resistive, giving a higher slope. At this moment of growth, the addition of CuSe binary preferred, and the presence of different phases will control the resistance values and will be less dependent on the CISe presence. This is a direct indication of the importance of the secondary phases on the electrical properties of CISe. However, after thermal treatment, the region II and III do not give significant change but in the region I, resistance decreases up to one order of magnitude. This change is due to the formation of the $\mathrm{CuSe}$ from the original $\mathrm{Cu}_{2} \mathrm{Se}$ and $\mathrm{Se}$ resistivity. Valdes et al. studied the electric response of the cells, current-voltage curves of a representative device such as $\mathrm{SnO}_{2}: \mathrm{F} / \mathrm{TiO}_{2}(100$ 
$\mathrm{nm}) / \mathrm{nc} \quad \mathrm{TiO}_{2} / \mathrm{In}_{2} \mathrm{Se}_{3} / \mathrm{CISe} /$ graphite. $^{[125]}$ This combination shows very good diode behavior with a rectification ratio higher than 100 at $\pm 1 \mathrm{~V}$.

The complexing agent is used to reduce the activity of copper ions and to shift the copper deposition potential in the negative direction. It is also used to promote the formation of more crystalline compounds. Frontini et al. studied the effect of the acidic electrolyte bath on the electrical properties of CISe prepared by ED on dense and nanostructured $\mathrm{TiO}_{2} \cdot{ }^{[146]} \mathrm{In}$ the preparation of CISe film, citric acid was used as a complexing agent. In the presence of citrate, charge transfer reactions occur in several steps, lowering the deposition rate and improving the overall quality of the film. It also contributes to buffering the solution $\mathrm{pH}$. In this study, the electrochemical behavior of the CISe system was studied by cyclic voltammetry on different substrates. The voltammetric responses on $\mathrm{TCO} / \mathrm{d}-\mathrm{TiO}_{2}$ at $\mathrm{pH} 4$ and 6 was obtained. In both solutions, two cathodic peaks were observed. Only a slight difference in the position of the cathodic peak was observed ($0.91 \mathrm{~V}$ at $\mathrm{pH} 6$ and $-1.10 \mathrm{~V}$ at $\mathrm{pH} 4)$. This difference is in good agreement with that expected in response to the $\mathrm{pH}$ variation. The voltammetric response on $\mathrm{TCO} / \mathrm{d}-\mathrm{TiO}_{2} / \mathrm{nc}-\mathrm{TiO}_{2}$ at $\mathrm{pH} 4$ and 6 explains that the cathodic peak was observed $(-1.29 \mathrm{~V})$ at $\mathrm{pH} 4$ and $(-0.925 \mathrm{~V})$ at $\mathrm{pH} 6$. The higher current densities are likely due to the nano-porous substrate. They concluded that $0.8 \mathrm{~V}$ is chosen as a suitable potential to produce the CISe film.

\subsection{Photo-electrochemical Properties}

The thin-film solar cell is characterized by I-V measurements in the dark and under illumination. The most important parameters of the solar cell are open circuit voltage $\left(V_{o c}\right)$, short circuit current $\left(I_{s c}\right)$, fill factor $(F F)$ and efficiency $(\eta)$, etc. These parameters can be derived from the I-V curve, which is measured under illumination. Frontini et al. studied the photo-response of the CISe film, which was deposited on the $\mathrm{TiO}_{2}$ substrates with complexing agent citric acid. ${ }^{[146]}$ The dark response indicates the diode behavior with good rectification. Anincrement in the current can also be seen when the sample is illuminated and for potential values higher than $0.5 \mathrm{~V}$. Under radiation, the presence of the nanostructured $\mathrm{TiO}_{2}$ improves the performance of the cell. This is probably due to the bigger contact surface between the $\mathrm{n}$ - and $\mathrm{p}$-type semiconductors. Smaller differences are found in the current increment for CISe deposited on different substrates. The low energy conversion in the illuminated I-V curve can also be associated with fast electron-hole recombination in the $\mathrm{TiO}_{2} / \mathrm{CISe}$ interface when the values of the $\mathrm{V}_{\text {oc }}$ and $\mathrm{I}_{\mathrm{sc}}$ are minimum. The presence of a photocurrent proves the benefit of electrodepositing CISe using slightly acidic electrolytes on top of a nano-crystalline substrate. Huang et al. further analyzed the CISe sample, which was deposited on the flexible substrate. ${ }^{[119]}$

The photocurrent density versus the potential for annealed CISe film was obtained under dark/illumination condition. The $\mathrm{Cu} / \mathrm{In}$ ratio of the CISe film is 1.10 and 0.91 . It is observed that the cathode photocurrent increased in the direction of the cathode potential, i.e., it shows the CISe film with p-type conductivity while the n-type conductivity of the sample. The flat band potential $\left(\mathrm{V}_{\mathrm{fb}}\right)$ of the $\mathrm{p}$ - and n-type conductivity was found to be -0.85 and $-0.82 \mathrm{~V}$, respectively. Dharmadasa et al. discussed the photo-electrochemical properties of the electrodepositedCISe layer. ${ }^{[121]}$ In this case, the CISe film was deposited by immersing the material layers in a suitable electrolyte, $0.01 \mathrm{M} \mathrm{In}\left(\mathrm{SO}_{4}\right)_{3}$. The potential difference between the sample and a graphite counterelectrodewas measured under dark and white illumination conditions. The difference between the measured potential values provides the PEC signal, which is the $\mathrm{V}_{\text {oc }}$ of the junction under illumination.

The polarity of the PEC signal determines the electrical conductivity type of the layer and the magnitude of the signal, indicating the suitability of the doping concentration of the semiconducting layer for fabricating electronic devices. ${ }^{[182]}$ The information that the $\mathrm{p}^{+}$materials are deposited at cathodic potential less than $2.20 \mathrm{~V}$, P-type material deposited at cathodic potential range $2.20 \mathrm{~V}$ to $2.34 \mathrm{~V}$, intrinsic material at $2.35 \mathrm{~V}$, and n-type material at 2.36 to $2.80 \mathrm{~V}$ and $\mathrm{n}$ ${ }^{+}$materials above $2.80 \mathrm{~V}$. Once these voltage values were established, any desirable semiconductor layer could be grown from this particular bath. Theoretically, the maximum value of the $\mathrm{V}_{\mathrm{oc}}$ is calculated by dividing the bandgap energy by the charge of an electron $\left(\mathrm{E}_{0} / \mathrm{e}\right)$. $^{[183]}$

The conversion efficiency of the solar cell is simply the ratio of maximum power output to the incoming power. These all electrical parameters are depending on the bandgap energy value of the absorber material. The $\mathrm{V}_{\mathrm{oc}}$ and $\mathrm{FF}$ of the solar cell are increased by increasing bandgap energy but $\mathrm{I}_{\mathrm{sc}}$ decreases correspondingly. The optimum band gap value for the absorber material of a solar cell is about $1.5 \mathrm{eV}$ which results in a theoretical maximum efficiency of $30 \%{ }^{[1]}$ The efficiency of the solar cell depends on the thickness of the absorber material (CISe) and the buffer layer (CdS). As the thickness increases, the current density is improved. This is due to the increase in the photogenerated carriers in the absorber layer consequent on the increase in optical absorption. An increase in the grain size with increasing the thickness was also observed. There is a certain limit of thickness, after that thickness, the efficiency is decreased. ${ }^{[184]}$

\section{Post-deposition treatment}

CISe films were subjected to post-deposition treatments that included crystallinity improvement by annealing as well as etching. The main purpose of treatment is to improve the properties of the films to match better for photovoltaic purposes.

\subsection{Annealing}

Annealing of the CISe thin films can be deon at different temperatures in various atmospheres such as vacuum, air, argon, $\mathrm{H}_{2} \mathrm{~S}, \mathrm{~N}_{2}$, etc. The main purpose of this treatment is to improve the film properties viz. crystal structure, surface 
morphology, grain size, etc. The deposited films contain many impurities due to the precursor solutions and also contain some defects such as voids, pinholes, etc. ${ }^{[183]}$ The annealing process decreases unwanted defects besides removing the impurities. It is an accepted fact that the properties of the films also depend on the crystal structure and grain size.

Heat treatment not only improved the crystallinity but also increased the grain size of the film material. Araujo et al. synthesized CISe thin films on different substrates from the alkaline medium by using ED. ${ }^{[122]}$ The study was carried out at $\mathrm{pH} 8.5$ using di-ethylenediamine as a complexing agent for the $\mathrm{Cu}^{2+}$ ion. The as-deposited films were amorphous. Typical XRD patterns show the characteristic peaks (112), (220), (204), (312), and (116) for a CISe annealed film on Al, ITO glass and steel. These peaks correspond to the chalcopyrite phase of the CISe. Additionally, other observed diffraction peaksare are ascribed to $\mathrm{In}_{2} \mathrm{O}_{3}$, which could be formed during thermal treatment. A considerable amount of $\operatorname{In}_{2} \mathrm{O}_{3}$ could be formed during the annealing of the film deposited on $\mathrm{Al}$ and steel at $500^{\circ} \mathrm{C}$. This can occur by reacting with surface oxides of the substrate. XRD pattern of CISe film on ITO shows a minor amount of $\operatorname{In}_{2} \mathrm{O}_{3}$. So, ITO is a better option as compared to the other substrate. Volobujeva et al. prepared CISe films by one step ED of CISe films, which were deposited on Mo-coated soda-lime glass substrate ${ }^{[185]}$

The effect of thermal treatment in a vacuum and under selenium vapor pressure on the composition and structure of CISe has been investigated. Annealing in the atmosphere of Se vapor was provided in two-zone evacuated ampoules. The pressure of selenium vapor was controlled by the temperature of the Se source zone and varied from 0.01 to $13 \mathrm{~m}$ bar. The duration of the annealing was $30 \mathrm{~min}$. At the end of annealing, the sample was pulled out and cooled down to room temperature. The duration of vacuum thermal treatments was in the range from $15 \mathrm{~min}$ to $12 \mathrm{~h}$. The cross-section of the CISe film was annealed under Se vapor pressure of $13 \mathrm{~m}$ bar and vacuum. The annealing temperature was $450^{\circ} \mathrm{C}$. The asdeposited films with thickness $1 \mu \mathrm{m}$ are compact, uniform, and adherent. The formation of $\mathrm{MoSe}_{2}$ interlayer was observed in films thermally treated in selenium atmosphere as a result of diffusion of Se through CISe film and following reaction with Mo back contact layer. However, the thickness $\mathrm{MoSe}_{2}$ layer grows with increasing the Se vapor pressure. At Se pressure $0.01 \mathrm{~m}$ bar, it was $30 \mathrm{~nm}$, at Se pressure about $13 \mathrm{~m}$ bar, the thickness of the $\mathrm{MoSe}_{2}$ layer was $300 \mathrm{~nm}$. The structure of films annealed in a vacuum seems more uniform and nanocrystalline (about $50 \mathrm{~nm}$ ) as compared with all Se vapor pressure-treated films.

\subsection{Etching}

The etching is the process of using strong acid to cut into the unprotected parts of a metal surface. This is a method of making a print from a metal plate that has been bitten with acid. CISe films prepared with an excess of $\mathrm{Cu}$ to promote the grain growth, need another processing step to remove separate binary phases as $\mathrm{Cu}_{2} \mathrm{Se}$ segregated on the surface. The prevalent method for removing segregated $\mathrm{Cu}-\mathrm{Se}$ and $\mathrm{Cu}-\mathrm{S}$ phases is chemical etching in the KCN solution. ${ }^{[186]}$ Another approach to modify the surface is an exposure of the surface to strong oxidants such as $\mathrm{Br},{ }^{[186]} \mathrm{H}_{2} \mathrm{O}_{2}$, ${ }^{[187]}$ permanganates, ${ }^{[189]}$ or complexes. ${ }^{[190]}$ Electrochemical oxidation is a useful surface treatment technology. Although different research groups have used electrochemical etching of CISe and CIS films for surface modification. Two different processing solutions and technologies were used for electrochemical etching: oxidation in alkaline solution and electrochemical reduction-oxidation cycling in an acid solution. The influence of both electrochemical etching on surface morphology and elemental composition of thin films and on the electrical parameters of the complete solar cell are discussed in many pieces of kinds of literature Kois et al.grew the CISe film on the ITO surface by ED and annealed in a hydrogen atmosphere at $400^{\circ} \mathrm{C} .{ }^{[186]} \mathrm{In}$ this literature, the microstructure of the film was studied using cross-sectional SEM pictures. The CISe thin films with a thickness of about $0.8 \mu \mathrm{m}$ were electrodeposited on an ITO covered glass plate and annealed in a vacuum and showed a dense, uniform structure. No grooves were detected on the surface.

As a result of the removal of $\mathrm{Cu}_{2} \mathrm{Se}$ in the etching process of CISe films, the grain structure of the film was revealed. The grain boundary cracks extending through the film were expanded. The chemical etching in $\mathrm{KCN}$ removes $\mathrm{Cu}_{2} \mathrm{Se}$ in addition to the surface from the inter grain area and leads to the formation of deep cracks through the film. At the crosssection of the electrochemically treated films, visible traces of corrosion occur. The films with large grains could be prepared by using the etching technique. It is also worth noting that the large grain films were easily optimized by chemical etching of the film with $\mathrm{Cu}$ rich compositions. Reports showed improved efficiency of solar cells when etched CISe thin film was used as an absorber layer. This etching process assumes importance in absorber layer depositions. Before the preparation of window layers, the $\mathrm{Cu}-\mathrm{Se}$ layer is removed by the $\mathrm{KCN}$ etching solution. The subsequent chemical etching of the layer in a KCN solution has shown to be successful in eliminating the copper selenide phases, which were responsible for the remaining sub-bandgap absorption. ${ }^{[191]}$

$\mathrm{KCN}$ etching removes conductive copper selenide from the surface of $\mathrm{Cu}$ rich films but does not affect matrix composition. The existence of a binary $\mathrm{Cu}$-Se secondary phase aggregated near the surface in the island regions of the film can be determined by electron probe microanalysis (EPMA) before etching the film in a $10 \% \mathrm{KCN}$ solution. It is proposed that the $\mathrm{Cu}$-Se phase present during the growth of $\mathrm{Cu}$-rich CISe film enhances the mobility of atom on the substrate surface allowing the film to grow epitaxially to a critical thickness. Bereznevet al. prepared CISe film by ED technique. ${ }^{[192]}$ The XRD patterns of as-deposited, annealed, and etched CISe films were obtained. It can be seen that the as-deposited film is polycrystalline with diffraction peaks corresponding to 
either chalcopyrite or sphalerite phase. However, owing to the poor crystallinity of the film, it is difficult to determine the chalcopyrite phase. The formation of the chalcopyrite phase was observed for the annealed film. The CISe preferred orientations (112), (220), and (116) for the film after annealing in vacuum were observed, which may be attributed to the recrystallization and grain growth.

\section{Application of CISe in solar cells}

In 1883 , the first solar cell was built by Charles Fritts, who coated the semiconductor selenium with an extremely thin layer of gold to form the junctions ( $1 \%$ efficiency). The demand for convenient energy such as electrical energy is expected to grow in the future against the background of global environmental problems. Solar energy needs to convert into electrical energy, which is one of the most abundant, nonpollutants, and inexhaustible source of energy. The main candidates for low-cost thin-film solar cell materials are amorphous hydrogenated silicon (a-Si:H), CdTe (cadmium telluride), and CISeand its alloys with Ga and/or S. ${ }^{[193-194]}$ Of these, amorphous silicon solar cells currently have the largest market share. ${ }^{[195]}$ The absorption coefficient of amorphous silicon is higher than that of crystalline silicon, which enables its use in the thin-film form, and its bandgap is closer to the ideal value of about $1.5 \mathrm{eV}$. A serious disadvantage is the lightinduced degradation of solar cells made of this material, which leads to a drop in conversion efficiency from the initial value. ${ }^{[196]}$ The polycrystalline compound semiconductor materials (CdTe and $\left.\mathrm{Cu}(\mathrm{In}, \mathrm{Ga})(\mathrm{S}, \mathrm{Se})_{2}\right)$ do not suffer from light-induced degradation. The performances of CIS-based solar cells have even shown some improvement after illumination under normal operating conditions. The prepared samples were tested under two levels of irradiation. The changes were observed in $\mathrm{C}-\mathrm{V}$ characteristicsdemand long time degradation of CIGS solar cells. ${ }^{[197]}$ Another advantage is that they are direct bandgap materials with high absorption coefficients. The bandgap of CdTe $(1.4 \mathrm{eV})$ is very close to the ideal value. Despite that, the record efficiency for CdTe solar cells is only $16.5 \%$, about half of the theoretical value. ${ }^{[198]}$ Of the candidate thin-film polycrystalline materials for solar cells, CISe and CdTe are the most promising with both close to the pilot production stage. The maximum reported efficiency of'CISe-based cells is $14.1 \%$ for a small cell, ${ }^{[199]} 11.2 \%$ (aperture efficiency) for a $938-\mathrm{cm}^{2}$-area device array ${ }^{[200]}$, and $10.4 \%$ (aperture efficiency) for a $3961-\mathrm{cm}^{2}$-area panel. ${ }^{[201-202]}$ CdTe has achieved $13.4 \%$ in small-area devices ${ }^{[203]}$ and $7.3 \%$ efficiency for a $929-\mathrm{cm}^{2}$-area device array. ${ }^{[204]}$ CISe-based solar cells have achieved efficiencies of over $14 \%$. Only recently, quantitative models of the device operation have been developed based on the model result, ${ }^{[205-207]}$ it is likely that improvements in $\mathrm{J}_{\mathrm{sc}}$ and $\mathrm{FF}$, can be achieved by improved device design.

\subsection{Solid state solar cell (PV)}

The structure of this cell is quite complex since it contains several compounds as stacked films that may react with each other. High-efficiency solar cells based on CISehave all used heterojunctions between a p-type (absorber) layer of CISeor a related alloy, and a transparent n-type $\mathrm{CdS}, \mathrm{ZnSe}, \mathrm{ZnO}$, or related compound layer. Substrates are generally glass, which is attractive for potential large-scale device applications because it is available at low cost in large areas with very smooth surfaces. Solar cell preparation starts by the deposition of the p-type CISe absorber on the Mo-coated glass substrate, followed by the $\mathrm{CdS}$ or other weakly n-type buffer layer, doped $\mathrm{ZnO}$ (transparent oxide), metal grids, and an antireflecting coating. The obtained bulk conductivity of the CIS thin-film is p-type and the surface conductivity is n-type. ${ }^{[143]}$ The key component of the solar cell configuration is the polycrystalline absorber film i.e. CISe.

The performance of this material is strongly influenced by its grain size, grain orientation, loss mechanism originating from grain boundaries, and crystal defects. Regardless of the deposition method, the absorber films of CISe based highefficiency devices have smooth surface morphologies and consist of large density packed grains. The films are crystalline with a chalcopyrite structure, no additional phases are allowed in the films. Copper selenide phases as well as indium selenide phases especially are detrimental to the solar cell performance. ${ }^{[184]}$ The Mo layer acts as the ohmic back contact to the cell and also improves the adhesion between the glass substrates and the active layers. The deposition of a thin $(1 \mu \mathrm{m})$ molybdenum layer onto the glass substrate by electron-beam evaporation or sputtering is the first step in the fabrication process. The buffer layer also plays a very important role as a mechanical buffer. Since it protects the junction electronically and mechanically against the damage that may otherwise be induced by the oxide deposition. To improve the device performance, a $50 \mathrm{~nm}$ thick CdS buffer layer is deposited between the absorber and window layers ${ }^{[183]}$

The thickness as well as the deposition method of the CdS layer have a large impact on device performance. During the early days, the device structures consisted of a CISe/CdS junction with a thick (about $1-3 \mu \mathrm{m}$ ) CdS layer. ${ }^{[208-210]}$ Garg etal. reported the films were free from pinholes and cracks, and found that they were suitable for solar cell applications after annealing. [208]

The CdS layers of these devices were most often prepared by evaporation at substrate temperatures between RT and about $200^{\circ} \mathrm{C}$, or in some cases by sputtering and the CdS film was often doped with either In or Ga. For example, Stoltet al. reported the CuInSe cells with $14.8 \%$ efficiency with $513 \mathrm{mV}$ Voc, $71 \% \mathrm{FF}$ and $40.4 \mathrm{~mA} / \mathrm{cm}^{2}$ Jsc. In some cases, a CdS bilayer was used, ${ }^{[210-211]}$ consisting of a thinner high resistivity layer, prepared either by evaporation or chemical bath deposition and a thicker low-resistivity layer, doped with $2 \%$ In or Ga. Evaporated CdS has been used also in combination with the transparent conducting oxide layer ${ }^{\text {[214-219] }}$

Nowadays CBD is used almost exclusively. The CdS buffer layer is lattice and electronically matched to the CISe 
absorber film and it presence controls the density of the interface states and prevents the inter-diffusion species like $\mathrm{Cu}$, In, or Se etc. from the absorber into the $\mathrm{ZnO}$ window layer and vice versa. $\mathrm{ZnO}$ is the ideal window material due to its wide bandgap $(3.2 \mathrm{eV})$, higher temperature stability and the fact that it can be doped in any desired order. The rectifying junction was formed between absorber film p-type CISe film and ntype $\mathrm{ZnO}$ window layer. The solar cell structure is completed by used 1- $2 \mu \mathrm{m}$ thick $\mathrm{Al}$ grid contact on to $\mathrm{ZnO}$ window layer. Absorption of light in the CdS layer, the bandgap of which is $2.4 \mathrm{eV}$, decreases the short circuit current density. The absorption of light in $\mathrm{ZnO}$, in turn, is a less severe problem because its bandgap is higher, $3.2 \mathrm{eV}$. Therefore, a thinner CdS layer results in a better device performance due to reduced absorption of light. Pillai et al. predicted the efficiency of the CISe/CdS solar cell. ${ }^{[184]}$ The efficiency of this solar cell depends on the thickness of the CISe and CdS layer.

The CdS layer must be thick enough to obtain $\mathrm{V}_{\text {ocand }}$ fill factor. If the CdS layer is too thin or does not exist at all, recombination in the space-charge region of CISe increases, causing losses in $\mathrm{V}_{\mathrm{oc}}, \mathrm{FF}$, and spectral response. To reduce resistive losses, a $50 \mathrm{~nm}$ thick $\mathrm{Ni}$ layer can be included between the $\mathrm{ZnO}$ window layer and $\mathrm{Al}$ grid contacts. Photovoltaic structures based on the electrically conductive polymer are currently intensively investigated to produce low cost, large area, and flexible plastic photodiodes and solar cells. ${ }^{[220-221]}$ The configuration for all devices is based on the mechanism of photo-induced electron transfer across the internal or external donor-acceptor (D/A) heterojunction. Notable examples include polymer/carbon, ${ }^{[222]}$ polymer/polymer, ${ }^{[223]} \quad$ polymer/organic, ${ }^{[224]}$ and polymer/inorganic structures. Although a lot of electrically conductive polymers were synthesized, polyaniline (PANI) was one of the most intensively studied polymers during the last decade. Bereznev et al. explained the electrochemical synthesis of In rich n-type CISe film with a thickness of about $1 \mu \mathrm{m}$ on to glass/ITO substrates was performed potentiostatically at the potential $-900 \mathrm{mV}$ vs SCE. The p-type PANI layer was cast on to the glass/ITO/n-CISe substrate from PANI solution in chloroform. The thickness of the prepared PANI film was found at about $10 \mu \mathrm{m}$. Finally, the metal strip (Ag) was evaporated on to the polymer layer. Electrical contacts were made on the ITO and metal with silver epoxy. The photovoltaic properties of structure under white light illumination are superior from the tungsten halogen lamp with an intensity of $50 \mathrm{~mW} / \mathrm{cm}^{2}$.The intensity of light produced a $\mathrm{J}_{\mathrm{sc}}$ of $0.56 \mathrm{~mA} / \mathrm{cm}^{2}$ and a $\mathrm{V}_{\mathrm{oc}}$ of $31.3 \mathrm{mV}$. These photovoltaic properties investigated that at the high thickness of CISe film, $95 \%$ of the incident light was absorbed and thus only $5 \%$ of radiant power to reach the junction between the CISe and PANI layers. Therefore, thinner films could be used to improve the transmission of light.

The effective lifetime of photogenerated charge carriers 14 $\mu \mathrm{s}$ was determined from the experimental curve. Photovoltage change induced by switching the IR light on and off on the prepared ITO/CISe/PANI/Ag photovoltaic structure. It was induced reversibly and repeatedly by the on-off cycles of IR irradiation. The results of $\mathrm{C}-\mathrm{V}$ measurements (MottSchottky plot) at a frequency of $37 \mathrm{kHz}$ for prepared structure. The value of built-in potential $\mathrm{V}_{\mathrm{bi}}=-2.15 \mathrm{eV}$ was determined by extrapolation to $\mathrm{C}^{-2}=0 . \mathrm{M}$. Dharmadasa et al.developed a low cost, large area multilayer graded bandgap solar cell structures, CISe layers were grown using simplified ED. Dharmadasa etal. obtained bandgap variation together with electrical conduction type changes, which are necessary to fabricate variation together with electrical conduction type changes. ${ }^{[121]}$ This experimental work enables the simultaneous production of $\mathrm{p}-\mathrm{i}-\mathrm{n}$ type material layers together with bandgap variation in the region of $\sim 1.00-1.90 \mathrm{eV}$. XPS and XRF measurements confirm that it is possible to grow CISe layers with p-i-n-type electrical conduction. XRF, XPS, and PEC measurement show that $\mathrm{Cu}$-richness provides p-type conduction and In richness provides n-type conduction in electrodeposited CISe layers. In fabrication, glass/CG/n-CdS substrate as the cathode, and electrodeposited n-, i- and p-type CISe layers as absorbers, four layers (n-n-i-p) graded solar cell has been fabricated. After heat treatment at $350{ }^{\circ} \mathrm{C}$ in a selenium atmosphere, and etching in $\mathrm{NaOH}+\mathrm{Na}_{2} \mathrm{~S}_{2} \mathrm{O}_{3}$ solution, $2 \mathrm{~mm}$ diameter $\mathrm{Au}$ contacts were made for testing these solar cell structures. These preliminary device structures show promising rectification properties. Under illumination (AM 1.5), the devices are PV active producing typical values of $\mathrm{V}_{\mathrm{oc}} \sim 450 \mathrm{mV}, \mathrm{J}_{\mathrm{sc}} \sim 20 \mathrm{~mA} \mathrm{~cm}{ }^{2-}$ and $\mathrm{FF} \sim 0.56$. There are different types of solid-state solar cells.

\section{A) ETA solar cell}

ETA stands for extremely thin absorber, and ETA solar cell is an advanced photovoltaic design, where porous or structural material (2-10 $\mu \mathrm{m}$ in thickness) is coated with a layer of a light-absorbing inorganic semiconductor. ETA solar cell utilizing $\mathrm{CuInX}_{2}(\mathrm{X}=\mathrm{S}, \mathrm{Se}, \mathrm{Te})$ technology is being developed to achieve even greater efficiency and these have attracted attention because they required less space. One main feature of the ETA solar cell is the widely enlarged surface of the substrate, e.g. porous $\mathrm{TiO}_{2}$, covered by a thin absorber layer. Due to this arrangement, the absorption is strongly enlarged. For this purpose, the absorber film must follow the internal porous surface.

The ETA solar cell consists of an extremely thin-layer ofof CISe absorber material. It is sandwiched in between two transparent semiconductors having a very high bandgap (3.73 $\mathrm{eV}$ ), one semiconductor is p-type and another semiconductor is n-type. Schematic ETA solar cells belong, as well as dyesensitized and organic solar cells, to composite solar cells consisting of interpenetrating electron and hole conductors, between which an absorber is sandwiched. This allows using semiconductors with shallow diffusion length for the absorber.

Since the absorber is thin in comparison to the absorption length of the bulk semiconductor, the internal surface area has to be folded to increase the amount of material for absorption. 
ETA solar cells promise to be very cost-efficient since lowcost technologies can be applied. Applied materials are, for example, $\mathrm{TiO}_{2}$ or $\mathrm{ZnO}$ as electron conductors, ternary material used as hole conductors. ${ }^{[133]}$

\section{B) Tandem solar cell}

This solar is merely two cells stacked one on top of the other. The advantage here is used two different bandgaps of two semiconductors. The lower cell absorbs some of the light that passes through the upper cell. CISe is placed underneath GaAs. The tandem cell showed an AMO efficiency of $23 \%$ more than the solid-state solar cell but twice the weight of the single GaAs cell. ${ }^{[224]}$ The tandem cell represents a 2 to 3 present increase inefficiency. Where weight is not a major consideration, a tandem cell would be an excellent choice. Coutts et al. have analyzed the performance of tandem two junction cell and shown the optimum efficiency for the A.M. 1.5 spectrum occurs with a top cell of $1.7 \mathrm{eV}$ and a bottom cell of $1.1 \mathrm{eV}{ }^{[225]}$ These band gaps are tightly constrained for twoterminal cells, by the need to match photogenerated currents in the top and bottom cell. Wuet al. have recently fabricated a $15 \%$ four-terminal device based on CdTe and CISe. ${ }^{[226]}$ It is a multi-layered stack of thin films of different materials deposited onto a substrate. The key features to observe here are: (1) there are two single-type or three-layer cells (each with a $p-i-n$ configuration) stacked on top of one another; (2) these two single cells are physically inseparable from each other (as deposited in this device configuration). These two points are key to understanding how a tandem cell works, and why measurements performed on them are necessarily different from those done on a single device. Under white light illumination, then this would require the bottom i-layer to be much thicker and/or have a narrower energy bandgap than the top i-layer to have the same amount of optical absorption. Nanu et al. fabricated a nanocomposite $3 \mathrm{D}$ solar cell by using technique. ${ }^{[227]}$ This study focused on the low-cost preparation of thin-film $\mathrm{TiO}_{2} / \mathrm{CuInS}_{2}$ nanocomposite solar cells. However, we can manufacture 3 D solar cells based on the CISe thin film The active $p-n$ heterojunction is folded and fills in the space between the contacts. Light absorption and charge separation take place inside the nanocomposite. Cheap deposition techniques such as SP and industrial-grade chemicals of only $95 \%$ purity can now be used to obtain photovoltaic (PV) solar cells. Literature reveals the low-cost preparation of thin-film $\mathrm{TiO}_{2} / \mathrm{CuInS}_{2}$ nanocomposite $3 \mathrm{D}$ solar cells. However, due to poor quality of the obtained absorber, the conversion efficiency was very low, typically $1-2 \%$. To improve efficiency, CISe is a good choice for absorber material in 3-D solar cells. We can improve the quality of the thin film with considerable efficiency of 3-D solar cells.

\subsection{Liquid state solar cell (PEC)}

This solar cell mainly consists of a photo-electrode, electrolyte, and C-counter electrode. When the photoelectrode is illuminated by light, then a voltage is developed across the photoelectrode and counter electrode. This effect is called the photo-electrochemical effect. The counter electrode is used as graphite and photoelectrode as CISe thin film. Using the polarity of the voltage developed in the PEC cell under the illumination, one can find out the type of conductivity of the material. The current-voltage characterization is used to find out junction identity factor (n), fill factor (ff), power conversion efficiency $(\eta)$ of the solar cell, etc. According to the literature review, CISe based PEC solar cells were reported with a maximum efficiency of $9 \%{ }^{[228]}$ Danny et al. prepared PEC cell configuration $\mathrm{p}-\mathrm{CISe} / \mathrm{Polyiodide} / \mathrm{C}$ was formed. In that paper, anodic behavior occurs in the photo-voltage, it indicates the p-type nature of CISe. The I-V curve gives the fill factor and efficiency, it was found to be 49.00 and $0.80 \%$ respectively. ${ }^{[229]}$ The value of $\mathrm{R}_{\mathrm{s}}$ and $\mathrm{Ru}_{\mathrm{sh}}$ was found to be 5 and $10 \mathrm{k} \Omega$ respectively. Tembhurkar et al. prepared a PEC cell between spray pyrolytically deposited n-CISe/polysulphide nCISe photoanode has been prepared by Spon to $\mathrm{SnO}_{2}-$ deposited glass substrate, the effect of etching $\left(\mathrm{HCl}: \mathrm{HNO}_{3}=\right.$ $5: 1$ by volume) on photoanode properties has been studied. ${ }^{[162]}$ The solar cell parameters are calculated. $\left(\mathrm{V}_{\mathrm{oc}}=0.446 \mathrm{~V}, \mathrm{~J}_{\mathrm{sc}}=\right.$ $18.32 \mathrm{ma} / \mathrm{cm}^{2}, \mathrm{FF}=0.53$ and $\eta=6.22 \%$.

\section{Conclusion and future outlook}

An available literature survey on chemical methods reveals that it indeed offers an attractive method to prepare CISethinfilm materials for solar cells. The quality and properties of the thin films largely depend on the preparative parameters of the respective methods. The properties of the CISe thin films are easily tailored by adjusting or optimizing the preparative parameters, which in turn are suitable for a solar cell application. From a practical point of view, the relative metal concentrations in solution must be adjusted empirically to obtain a desired ratio of the metal in the film.

This review focuses on some low-cost methods, which are useful to prepare good CISe thin film. To lower the production costs of photovoltaic modules, alternative, low-cost deposition methods need to be developed. There is probable room for different deposition processes for different applications, that is, higher cost methods may be used in high-value applications like in satellites, where high efficiency is crucial. Whereas less expensive methods may be needed to achieve low prices for mass products. The latter may become more critical when photovoltaic become more and more conventional means of energy production.

Technology in the present century requires the miniaturization of the devices into nanometer size with the dramatically enhanced ultimate performance. This raises issues regarding new materials for achieving functionality and selectivity. Low-cost methods should be selected to give a good quality thin films. Chemical methods are the right choice for these objectives. These methods are useful to make nanostructure material, nano-phase, or nanostructured materials research. However, the nanocrystalline natures of the CISe thin films open the new window in the energies field 
of nanoscience technology. Indeed, the development of CISe thin films will help to improve solar cell efficiency and further research will produce innovation that will benefit industries and society.

\section{Acknowledgments}

The authors are thankful to the Indian Space Research Organization-Savitribai Phule Pune University, Pune Science, and Technology Cell (ISRO-SPPU STC) for partial financial assistant.

\section{Supporting Information}

Not applicable

Conflict of interest

There are no conflicts to declare.

\section{List of symbols and abbrevations}

\begin{tabular}{ll}
\hline Symbol & Abbreviation \\
\hline CISe & Copper Indium Di-selenide \\
$\mathrm{V}_{\mathrm{oc}}$ & Open Circuit Voltage \\
PVD & Physical Vapor Deposition \\
$\mathrm{CBD}$ & Chemical bath deposition \\
CED & Chemical Electro-deposition \\
SILAR & Successive Ionic Layer and adsorption reaction \\
SP & Spray Pyrolysis \\
F:SnO 2 & Fluorine doped Tin Oxide \\
OVC & Ordered vacancy compound \\
ITO & Indium doped tin oxide \\
M-CBD & Modified chemical bath deposition \\
$\mathrm{I}_{\mathrm{sc}}$ & Short Circuit Current \\
FF & Fill Factor \\
$\mathrm{H}$ & Efficiency \\
$\mathrm{J}_{\mathrm{sc}}$ & Short current density \\
ETA & Extremely Thin Absorber \\
$\mathrm{P}_{\mathrm{max}}$ & Maximum Power \\
RT & Room temperature \\
XRD & X Ray diffraction \\
A & Absorption Coefficient \\
\hline
\end{tabular}

\section{References:}

[1] H. M Pathan, C. D Lokhande. Bull. Mater. Sci., 2004, 27, 2 , doi: 10.1007/BF02708491.

[2] T. Terasako, U. Yuji, K. Tetsuya, S. Shirakat. Sol. Ene. Mate. \& Sol. Cells, 2006, 90, 262-275, doi: 10.1002/pssc.200669597

[3] J. Muller, J. Nowoczin, H. Schmitt, Thin Solid Film, 2006, 496, 364, doi: 10.1016/j.tsf.2005.09.077.

[4] M.V. Yakushev, A. V. Mudryi, V. F. Gremenok, E. P. Zaretskaya, V. B. Zalesski, Y. Feofanov, R.W. Martin, Thin Solid
Film, 2004, 133, 451-452, doi: 10.1016/j.tsf.2003.11.003.

[5] A.V. Postnikov, M.V. Yakushev, Thin Solid Film, 2004, 141, 451, doi: 10.1016/j.tsf.2003.11.005.

[6] A. Brummer, V. Honkimaki, P. Berwin, V. Probst, J. Palm, R. Hock, Thin Solid Film, 2003, 437, 297, doi: 10.1016/S00406090(03)00685-0.

[7] M.A. Contreras, M.J. Romero, B. To, F. Hasoon, R. Noufi, S. Ward, K. Ramanathan, Thin Solid Film, 2002, 204, 403 doi:10.1016/S0040-6090(01)01538-3.

[8] L. L. Kazmerski, M. S. Ayyagari, F. R. White, G. A. Sanborn, J. Vac. Sci. Technol., 1976, 13, 139, doi: 10.1116/1.568808

[9] K. W. Mitchell, C. Eberspacher, J. Omar, D. Pier, Proc. 20th IEEE Conf. Photovolt. Specialists, Las Vegas, 1988, 1384.

[10] J. E. Jaffe, A. Zunger, Phys. Rev. B, 1984, 29, 1882, doi: 10.1103/PhysRevB. 29.1882.

[11] K. W. Mitchell, Proc. 4th Int. Photovolt. Sol. Eng. Conf., $1989,889$.

[12] L. L. Kazmerski, S. Wagner, 'Current Topics in Photovoltaics, 1985, 1, 67.

[13] Fatima Zohra Satour, Ameur Zegadi, Infra. Phy. and Tech., 2019, 96, 238-243, doi: 10.1016/j.infrared.2018.11.035

[14] Ali Murat Soydan, Pinar Yilmaz, and Bahadur Tunaboylu, 2018, 7, doi:10.1155/2018/5187960.

[15] H. S. Min, S. Mandati, R. Chandran, A. Mallik, M. Arif, S. Bhuiyan and K.G. Deepa, Orient. J. Chem., 2019, 35, 01-13.

[16] M. Kemell, M. Rital, and M. Leskel, Solid State and Mater. Sci., 2005, 30, 1-31, doi: 10.1080/10408430590918341.

[17] T. Feurer, R. Carron, G. T. Sevilla, F. Fu, S. Pisoni, Y.E. Romanyuk, S. Buecheler, and A. N. Tiwari, Adv. Energy Mater. 2019, 9, 1901428, doi: 10.1002/aenm.201901428.

[18] R. R. Pottier, J. R. Sites, IEEE Trans. Elect. Devices., 1984, 31,571, doi:10.1109/T-ED.1984.21571.

[19] T. Irie, S. Endo, S. Kimura, Jpn.J. Appl. Phys.,1979, 18, 1303, doi: 10.1143/JJAP.18.1303.

[20] J. C. Garg, R.P. Sharma, K.C. Sharma, Thin Solid Film, 1988, 164, 269, doi: 10.1016/0040-6090(88)90148-4

[21] K. D. Becker, S. Wagner, Phys. Rev., (B), 1983, 27, 5240, doi: 10.1103/PhysRevB.27.5240.

[22] H. G. Bruhl, H. Neumann, T. Pfieffer, G. Kuhn, Phys. Status Solid(a), 1981, 66, 597

[23] P. W. Li, R.A. Anderson, R. H. Plovnick, J. Phys. Chem. Solids., 1979, 40, 333, doi: 10.1016/0022-3697(79)90113-6.

[24] L. Stephanie, G. Sheila, P. Ryne, Kulbinder, K.F. Chem. Mater.,2003, 15, 3142-3147, doi: 10.1021/cm034161o.

[25] J. E. Jaffe, A. Zunger; Phy. Rev. B, 1983, 28, 10, doi:10.1103/PhysRevB.28.5822.

[26] J. Zank, M. Mehlin, and H. P. Fritz, Thin Solid Film, 1996, 286, 259, doi: 10.1016/S0040-6090(95)08214-X.

[27] C. Guillen, M. A. Martınez, and J. Herrero, Vacuum, 2000, 58, 594, doi: 10.1016/S0042-207X(00)00355-9. 
[28] T. L. Chu, S. S. Chu, S. C. Lin, and J. Yue, J. Electrochem. Soc., 1984, 131, 2182, doi:10.1149/1.2116044.

[29] A. Garg, K. S. Balakrisnan, and A. C. Rastogi, J. Electrochem.Soc., 1994, 141, 1566, doi: 10.1149/1.2054963.

[30] A. C. Rastogi, K. S. Balakrisnan, R. K. Sharma, and K. Jain, Thin Solid Film, 1999, 357 179, doi: 10.1016/S00406090(99)00649-5.

[31] C. Guillen, and J. Herrero, Thin Solid Film, 1998, 323, 93, doi: 10.1016/S0040-6090(97)01038-9

[32] M. E. Calixto, and P. J. Sebastian, J. Mater. Sci,1998, 33, 339, doi: 10.1023/A:1004311527795.

[33] G. Hodes, T. Engelhardt, D. Cahen, L. L. Kazmerski, and C. R. Herrington, Thin Solid Film, 1985, 128, 93, doi: 10.1016/0040-6090(85)90338-4.

[34] S. R. Kumar, R. B. Gore, and R. K. Pandey, Thin Solid Film, 1993, 223, 109, doi: 10.1016/0040-6090(93)90733-6.

[35] H. P. Fritz and P. Chatziagorastou, Thin Solid Film, 1994, 247, 129, doi: 10.1016/0040-6090(94)90485-5.

[36] V. K. Kapur, B. M. Ba,sol, and E. S. Tseng, Sol. Cells, 1987, 21, 65, doi:10.1016/0379-6787(87)90105-0.

[37] P. P. Prosini, M. L. Addonizio, A. Antonia and S. Loreti, Thin Solid Film, 1996, 288, 90, doi: 10.1016/S0040-6090(96)08817-7. [38] M. Altosaar, E. Mellikov, J. Kois, Y. Guo, and D. Meissner, Proceedings of Joint International Meeting of The Electrochemical Society, Inc. and The International Society of ElectrochemistryParis, France, 1997, 1314.

[39] C. D. Lokhande, Mater. Chem. phy., 2005, 28, 145-149. doi: 10.1016/j.matchemphys.2005.03.051.

[40] R.W. Birkmire and E. Eser, Annu. Rev. Mater. Sci., 1997, 27, 625, doi: 10.1146/annurev.matsci.27.1.625.

[41] A. Goetzberger, J. Luther, and G. Willeke, Sol. Energy Mater. Sol. Cells, 2002, 74,1, doi: 10.1016/S0927-0248(02)00042-9

[42] R. W. Birkmire, Sol. Energy Mater. Sol. Cells, 2001, 65, 17, doi: 10.1016/S0927-0248(00)00073-8.

[43] A. Goetzberger and C. Hebling, Sol. Energy Mater. Sol. Cells,2000, 62, 1, doi: 10.1016/S0927-0248(99)00131-2

[44] A. Shah, P. Torres, R. Tscharner, N. Wyrsch, and H. Keppner, Science, 1999, 285, 692, doi: 10.1126/science.285.5428.692.

[45] J. F. Guillemoles, L. Kronik, D. Cahen, U. Rau, A. Jasenek, and H.-W. Schock, J. Phys. Chem. B,2000, 104, 4849, doi: 10.1021/jp993143k.

[46] U. Rau and H.W. Schock, Appl. Phys. A: Mater. Sci. Process, 1999, 69, 131, doi: 10.1007/s003390050984.

[47] A. Rockett and R. W. Birkmire, Appl. Phys., 1991, 70, R81, doi: 10.1063/1.349175.

[48] B. J. Stanbery, Rev. Solid State Mater. Sci., 2002, 27, 73, doi: 10.1080/20014091104215.
[49] H.-W. Schock and R. Noufi, Prog. Photovolt.: Res. Appl., 2000, 8,151, doi: 10.1002/(SICI)1099-

159X(200001/02)8:1<151::AID-PIP302>3.0.CO;2-Q.

[50] S. Siebentritt, Thin Solid Film, 2002, 1, 403-404, doi: 10.1016/S0040-6090(01)01525-5

[51] ASTM E927-91. Standard specification for solar simulation for terrestrial photovoltaic testing.

[52] ASTM G159-98. Standard tables for references solar spectral irradiance at air mass 1.5: Direct normal and hemispherical for a37 tilted surface (E891 \& E892).

[53] D. M. Chapin, C. S. Fuller, and G. L. Pearson, J. Appl. Phys., 1954, 25, 676, doi: 10.1063/1.1721711.

[54] M. A. Green, K. Emery, D. L. King, S. Igari, and W. Warta, Prog. Photovolt: Res. Appl., 2003, 11, 347, doi: 10.1002/pip.499.

[55] V. M. Fthenakis, S. C. Morris, P. D. Moskowitz, and D. L. Morgan, Prog. Photovolt.: Res. Appl., 1999, 7, 489, doi: 10.1002/(SICI)1099-159X(199911/12)7:6<489::AID-

PIP287>3.0.CO;2-N.

[56] T. Wada, N. Kohara, S. Nishiwaki, and T. Negami, Thin Solid Film, 2001, 387, 118, doi: 10.1016/S0040-6090(00)01846-0.

[57] D. Schmid, M. Ruckh, and H.W. Schock, Sol. Energy Mater. Sol. Cells, 1996, 41-42, 281, doi: 10.1016/0927-0248(95)001077.

[58] H. W. Schock and U. Rau, Physica B, 2001, 1081, 308-310, doi: 10.1016/S0921-4526(01)00863-8.

[59] T. F. Ciszek, J. Cryst. Growth, 1984, 70, 405, doi: 10.1016/0022-0248(84)90294-X.

[60] J. H. Ermer and R. B. Love, European patent application, July 10, 1986.

[61] A. Rockett, T. C. Lommasson, L. C. Yang, H. Talieh, P. Campos, and J. A. Thornton, J. Appl. Phys., 1991, 70, 1505.

[62] I Mart and J. Santamaria, E. Iborra, G. Gonzalez-Diaz, and F. Sanchez- Quesada, J. Appl. Phys., 1987, 62, 4163, doi: 10.1063/1.339135.

[63] F. Sanchez-Quesada, C. Case, G. Gonzalez-Diaz, R. Beaulieu, and J. J. son, A. E. Hill, and D. G. Armour, Jpn. J. Appl. Phys, 1980, 19, 15, doi: 10.7567/JJAPS.19S3.15.

[64] N. A. K. Abdul-Hussein, A. N. Y. Samaan, R. D. Tomlinson, Cryst. Res. Technol. 1985, 20, 509.

[65] G. Dagoury, D. Vigner, and R. Lesueur, Proceedings of the 9th Inter-national Vacuum Congress and Sth International Conference on SolidSurfaces, Sept. 26, 1, 1983, edited by J. L. Segovia, ASEVA, Madrid, Spain, 1983, 128

[66] A. N. Y. Samaan, N. Abdul-Karim, N. Abdul-Hussein, R. D. Tomlin-son, A. E. Hill, and D. G. Armour, Jpn. J. Appl. Phys., 1980, 19, 15, doi: 10.7567/JJAPS.19S3.15.

[67] J. A. Thornton, Sol. Cells, 1987, 21, 41, doi: 10.1016/03796787(87)90103-7. 
[68] J. A. Thornton, T. C. Lommasson, H. Talieh, and B.-H. T seng, Sol. Cells, 1988, 24,1, doi: 10.1016/0379-6787(88)900300 .

[69] J. Santamaria, I. Martil, E. Iborra, G. Gonzalez-Diaz, and F. Sanchez-Quesada, Sol. Cells, 1990, 28, 31, doi: 10.1016/0379. 6787(90)90036-5.

[70] B. Schumann, A. Tempel, and G. Kuhn, Sol. Cells, 1986, 16, 43, doi: 10.1016/0379-6787(86)90074-8.

[71] N. Takenoshita, Sol. Cells, 1986, 16, 65, doi: 10.1016/03796787(86)90075-X

[72] F. J. Pern, J. Goral, R. J. Matson, T. A. Gessert, and R. Noufi, Sol. Cells,1988, 24, 81, doi: 10.1016/0379-6787(88)90038-5.

[73] X. Qui and I. Shih, Can. J. Phys.,1987, 65, 1011, doi: 10.1139/p87-163

[74] Y. Ueno, H. Kawai, T. Sugiura, and H. Minoura, Thin Solid Films, 1988, 157, 159, doi: 10.1016/0040-6090(88)90356-2

[75] D. Pan, X. Zhang, G. Yang, Y. Shang, F. Su, Q. Hu, R. R. Patil, H, Liu, C. Liu and Z. Guo, Ind. Eng. Chem. Res., 2020, 59, 20371-20381, doi: 10.1021/acs.iecr.0c04510.

[76] G. Hades and D. Cahen, Sol. Cells, 1986, 16, 245, doi: 10.1016/0379-6787(86)90088-8.

[77] F. J. Garcia and M. S. Tomar, Jpn. J. Appl. Phys.,1983, 22, 535, doi: 10.7567/JJAPS.22S1.535.

[78] N. Arita, N. Suyama, Y. Kita, S. Kitamura, T. Hibino, N. Takada, K. Omura, N. Ueno, and M. Murozono, Proceedings of the 20th Institute of Electrical and Electronics Engineers Photovoltaic Specialists Conference, Las Vegas, September 2630, 1988 (Institute of Electrical and ElectronicsEngineers, New York, (1988). 1650.

[79] T L. Chu, S. S. Chu, S. C. Lin, and J. Yue, J. Electrochem. Sot., 1984, 131, 2182, doi: 10.1149/1.2116044

[80] G. Hades, T. Engelhard, D. Cahen, L. L. Kazmerski, and C. R. Herrington, Thin Solid Films, 1985, 128, 93, doi: 10.1016/0040-6090(85)90338-4.

[81] V. K. Kapur, B. M. Basal, and E. S; Tseng, in Proceedings of the $7^{\text {th }}$ International Conference on Ternary and Multinary Compounds, edited by S. K. Deb and A. Zunger (Materials Research Society, Pittsburgh,1986, 219.

[82] D. Lincot, M. Froment, and H. Cachet, in Advances in ElectrochemicalScience and Engineering, Vol. 6, R. C. Alkire, D. M. Kolb, Eds., Wiley-VCH, Weinheim, Germany, (1999) 165.

[83] R. N. Bhattacharya, J. Electrochem.Soc. 1983, 130, 2040, doi: $10.1149 / 1.2119516$.

[84] J. C. Garg, R. P. Sharma, and K. C. Sharma, Thin Solid Films, 1988, 164, 269, doi: 1016/0040-6090(88)90148-4.

[85] R. N. Bhattacharya, W. Batchelor, J. E. Granata, F. Hasoon, H. Wiesner, K. Ramanathan, J. Keane, and R. N. Noufi, Sol. Energy Mater. Sol. Cells, 1998, 55, 83, doi: 10.1016/S09270248(98)00049-X.
[86] P. P. Hankare, K. C. Rathod, P. A. Chate, A.V. Jadhav, I.S. Mulla, J. Alloy and Comp., 2010, 78, doi: 10.1016/j.jallcom.2010.03.215.

[87] R.H. Bhari, L. A. Patil, P.S. Sonawane, M.D. Mahanubhav, V. R. Patil, P. K. Khanna, Mater. Letts., 2007, 61, 2058-2061, doi: 10.1016/j.matlet.2006.08.015.

[88] S. M. Chauhan, S. H. Chaki, M.P. Deshpande, Jiten P. Tailor, A. J. Khimani Maters. Sci. Semicon. Proce., 2018, 74, 329-335, doi: 10.1016/j.mssp.2017.11.008.

[89] R.N. Bhattacharya, A.M. Fernandez, M.A. Contreraz, J. Keane, K. Tennant, K. Ramanathan, J. R. Tuttle, R.N. Noufi, A. M. Hermann, J. Electrochem. Soc., 1996, 43, 854, doi: 10.1016/0038-1101(96)00045-7.

[90] R. N. Bhattacharya, J.F. Hiltner, W. Batchelor, M.A. Contreras, R.N. Noufi, J.R. Sites, Thin Solid Film, 2000, 361, 396-399, doi: 10.1016/S0040-6090(99)00809-3

[91] S. Jost, F. Hergert, R. Hock, J. Schulze, A. Kirbs, M. Vob, M. Purwins, M. Schmid, Sol. Energy Mater. Sol. Cells, 2007, 91, 636, doi: 10.1016/j.solmat.2006.12.012.

[92] Y. Ueno, H. Kawai, Sugiura, H. Minoura, Thin Solid Film, 1988, 157, 159-168, doi: 10.1016/0040-6090(88)90356-2.

[93] L. Thouin, S. Massaccesi, S. Sanchez, and J. Vedel, J. Electroanal. Chem., 1994, 374, 81, doi: 10.1016/00220728(94)03352-8.

[94] T. Pottier and G. Maurin, J. Appl. Electrochem. 1989, 19, 361, doi: 10.1007/BF01015237.

[95] A. N. Molin, A. I. Dikusar, G. A. Kiosse, P. A. Petrenko, A. I.Sokolovsky, and Yu. G. Saltanovsky, Thin Solid Film, 1994, 237, 66, doi: 10.1016/0040-6090(94)90239-9

[96] A. N. Molin and A. I. Dikusar, Thin Solid Films, 1994, 237, 72, doi: 10.1016/0040-6090(94)90240-2.

[97] M. G. Ganchev and K. D. Kochev, Sol. Energy Mater. Sol. Cells, 1993, 31, 163, doi: 10.1016/0927-0248(93)90048-8

[98] C. Guillen, and J. Herrero, J. Electrochem. Soc., 1994, 141, 225, doi: 10.1149/1.2054688.

[99] Y. Ueno, H. Kawai, T. Sugiura, and H. Minoura, Thin Solid Films, 1988, 157, (1988) 159, doi: 10.1016/00406090(88)90356-2.

[100] R. P. Raffaelle, H. Forsell, T. Potdevin, R. Friedfeld, J. G. Mantovani, S. G. Bailey, S. M. Hubbard, E. M. Gordon, and A.F. Hepp, Sol. Energy Mater. Sol. Cells,1999, 57, 167, doi: 10.1016/S0927-0248(98)00180-9.

[101] E. Tzvetkova, N. Stratieva, M. Ganchev, I. Tomov, K. Ivanova, and K. Kochev, Thin Solid Films, 1997, 311, 101, doi:10.1016/S0040-6090(97)00263-0.

[102] T. Edamura, and J. Muto, J. Mater. Sci. 1994, 5, 275, doi: 10.1007/BF00921251.

[103] A. Kampmann, V. Sittinger, J. Rechid, and R. ReinekeKoch, Thin Solid Films, 2000, 361, 309, doi: 10.1016/S00406090(99)00863-9. 
[104] N. B. Chaure, J. Young, A. P. Samantilleke, and I. M. Dharmadasa, Sol. Energy Mater. Sol. Cells, 2004, 81, 125, doi: 10.1016/j.solmat.2003.10.001.

[105] R. N. Bhattacharya, J. F. Hiltner, W. Batchelor, M. A. Contreras, R. N. Noufi, and J. R. Sites, Thin Solid Films, 2000, 361, 396, doi: 10.1016/S0040-6090(99)00809-3.

[106] R. N. Bhattacharya, W. Batchelor, K. Ramanathan, M. A. Contreras, and T. Moriarty, Sol. Energy Mater. Sol. Cells, 2000, 63, 367, doi: 10.1016/S0927-0248(00)00056-8.

[107] P. Garg, A. Garg, A. C. Rastogi, and J. C. Garg, J. Phys. D: Appl.Phys.,1991, 24, 2026, doi: 10.1088/0022-3727/24/11/018 [108] S. N. Sahu, R.D. L. Kristensen, and D. Haneman, Sol. Energy Mater., 1986, 18, 385, doi: 10.1016/01651633(89)90063-4.

[109] Y. Sudo, S. Endo, and T Irie, Jpn. J. Appl. Phys.,1993, 32, 1562, doi: 10.1143/JJAP.32.1562.

[110] M. C. F. Oliveira, M. Azevedo, and A. Cunha, Thin Solid Films, 2002, 405, 129, doi: 10.1016/S0040-6090(01)01720-5.

[111] M. E. Calixto and P. J. Sebastian, Sol. Energy Mater. Sol. Cells, 2000, 63, 335, doi: 10.1016/S0927-0248(00)00053-2.

[112] R. Ugarte, R. Schrebler, R. C'ordova, E. A. Dalchiele, and H. Gomez, Thin Solid Films, 1999, 340, 117, doi: 10.1016/S00406090(98)01361-3.

[113] C. D. Lokhande, J. Electrochem. Soc. 1987, 134, 1727, 10.1149/1.2100745, doi: 10.1149/1.2100745.

[114] S. Nomura, K. Nishiyama, K. Tanaka, M. Sakakibara, M. Ohtsubo, N. Furutani, and S. Endo, Jpn. J. Appl. Phys., 1998, 37, 3232, doi: 10.1143/JJAP.37.3232.

[115] S. N. Qiu, L. Li, C. X. Qiu, I. Shih, and C. H. Champness, Sol. Energy Mater. Sol. Cells, 1995, 37, 389, doi: 10.1016/09270248(95)00033-X.

[116] M. Pourbaix, Atlas of Electrochemical Equilibria in Aqueous Solutions, Pergamon Press, New York, 1966.

[117] M. Kemell, Academic dissertation, 2003

[118] S. Beyhan, S. Suzer, F. Kardirgan, Sol. Energy Mater. Sol. Cells, 2007, 91, 1922-1926, doi: 10.1016/j.solmat.2007.06.017. [119] C. J. Huang, T. H. Meen, M. Y. Lai, W. R. Chen, Sol. Energy Mater. Sol. Cells, 2004, 82, 553-565, doi: 10.1016/j.solmat.2003.12.008.

[120] J.S. Welling, A. P. Samantilleke, S.N. Heavens, P. Warren, I.M. Dharmadasa, Sol. Energy Mater. Sol. Cells, 2009,93, 1518 1523, doi: 10.1016/j.solmat.2009.03.031.

[121] I. M. Dharmadasa, R. P. Burton, M. Simmonds, Sol. Energy Mater. Sol. Cells, 2006, 90, 2191-2200, doi: 10.1016/j.solmat.2006.02.028.

[122] J. Araujo, R. Ortíz, A. López-Rivera, J.M. Ortega, M. Montilla, D. Alarcón, J Solid State Electrochem, 2007, 11, 407412, doi: 10.1007/s10008-006-0162-7.
[123] K. T. L. De Silva, W. A. A. Priyantha, J.K.D.S. Jayanetti, B.D. Chithrani, W. Siripala, K. Blake, I.M. Dharmadasa, Thin Solid Film, 2001, 382, 158-163, doi: 10.1016/S00406090(00)01185-8.

[124] E. Saucedo, C.M. Ruiz, E. Chasseing, J.S. Jaime-Ferrer, P.P. Grand, G. Savidand, V. Bermudez, Thin Solid Film, 2010, 518, 3674-3679, doi: 10.1016/j.tsf.2009.09.113.

[125] M. Valdes, M. Vazquez, A. Goossens, Electrochimica Acta, 2008, 54, 524-529, doi: 10.1016/j.electacta.2008.07.036.

[126] Y. Sudo, S. Endo, Irie, T., Appl. Phys., 1993, 32, 1562-1567, doi: 10.1143/JJAP.32.1562.

[127] N. Khare, G. Razzini, L.P. Bicelli, Thin Solid Film, 1990, 186, 113-128, doi: 10.1016/0040-6090(90)90505-8.

[128] C.P. Chien, S.B. Fine, T.L. Chu, S.S. Chu, Polycrystalline Thin Film Review Meeting, SERI, Golden, Co, 1984, 43.

[129] J.L. Xu, X.F. Yao, J.Y. Feng, The influence of the vacuum annealing process on electrodeposited CuInSe 2 film, Sol. Energy Mater. Sol. Cells, 73(2002) 203-208

[130] R.N. Bhattacharya, Solution growth and electrodeposited $\mathrm{CuInSe}_{2}$ thin films $J$ electrochem. Soc., 1983, 130, 2040, doi: $10.1149 / 1.2119516$

[131] T. Pottier, G. Maurin, J. Appl. Electrochem., 1989, 19, 361367, doi: 10.1007/BF01015237.

[132] J. S. Wellings, N.B. Chaure, S.N. Heavens, I.M. Dharmadasa, Thin Solid Film, 2008, 516, 3893-3898, doi: 10.1016/j.tsf.2007.07.156.

[133] C. Guillen, J. Herrero, Sol. Energy Mater. Sol. Cells, 1996, 43, 47-57, doi: 10.1016/0927-0248(95)00163-8.

[134] P. Garg, A. Garg, A.C. Rastogi, J.C. Garg, J. Phys. D: Appl. Phys., 1991, 24, 2026-2031, doi: 10.1088/0022-3727/24/11/018 [135] A. Ashour, A. A. Ramdhan, K. Abd El-Hady, A.A. Akl, J. Mater.Sci.: Mater. Electron, 2008, 16, 599, doi: 10.1007/s10854005-3233-0.

[136] S.N. Sahu, R.D.L Kristensen, D. Haneman, Sol. Energy Mater., 1989, 18, 385-397, doi: 10.1016/0165-1633(89)900634.

[137] R. Pal, K. K. Chattopadhyay, S. Chaudhari, A. K. Pal,Sol. Energy Mater. Sol. Cells, 33, 241, doi:10.1016/09270248(94)90210-0.

[138] M.E. Calixto, P. J. Sebastian, Sol. Energy Mater. Sol. Cells, 2000, 70, 335-345, doi: 10.1016/S0927-0248(00)00053-2.

[139] P.J. Sebastian, M.E. Calixto, R.N. Bhattacharya, R. Noufi, Sol. Energy Mater. Sol. Cells, 1999, 59, 125-135, doi: 10.1016/S0927-0248(99)00037-9.

[140] S. Bereznev, J. Kois, I. Golovtsov, A. Opik, E. Mellikov Thin solid films, 2006, 511, (2006) 425-429, doi: 10.1016/j.tsf.2005.11.074. 
[141] M. Benaicha, N. Benouattas; V. Benazzouz; Ouahab L. Sol. Energy Mater. Sol. Cells, 2009, 93, 262-266, doi: 10.1016/j.solmat.2008.10.014.

[142] T. Whang, V. Hsieh; Y. Kao; S. Lee, Appl.Sur. Sci., 2009, 255, 4600-4605, doi: 10.1016/j.apsusc.2008.11.081

[143] E. Tzvetkova, M. Ganchev; I. Tomov; K. Kochev, Thin Solid Films, 1997, 311, 101-106.

[144] A.N. Molin, A.I. Dikusar, G.A. Kiosse, P.A. Petrenko, A.I. Sokolovsky, Yu.G. Saltanovsky, Thin Solid Films, 1994, 237, $66-$ 71, doi: 10.1016/0040-6090(94)90239-9.

[145] J. Yang, Z. Jin, C. Li, W. Wang, Y. Chai, Electrochem. Commun., 2009,11, 711-714, doi: 10.1016/j.elecom.2008.12.062 [146] M.A. Frontini, M. Vazquez, J Mater Sci, 2010, 45, 2995 3000, doi: 10.1007/s10853-010-4300-3.

[147] S. Bereznev, J. Kois, E. Mellikov, A. Opik, Materials and technologies for photovoltaic applications from Estonia, Baltic polymer Symposium, 2001,148-154.

[148] M.C.F. Oliveira, M. Azevedo, A. Cunha, Thin Solid Films, 2002, 405, 129-134, doi: 10.1016/S0040-6090(01)01720-5.

[149] M.I. Alonso, K. Wakita, J. Pascual, M. Garriaga, A. Yamamoto, Cond-mat, 2001, 14, 0112048, doi: 10.1103/PhysRevB.63.075203.

[150] H. M. Pathan, J.D. Desai, C. D. Lokhande, Appl. Surf. Sci., 2002, 202 47-56, doi: 10.1016/S0169-4332(02)00843-7.

[151] J. Yang, Z. Jin, Y. Chai, H. Du, T. Liu, T. Wang, Thin Solid Film, 2009, 517, 6617-6622, doi: 10.1016/j.tsf.2009.04.050.

[152] H.M. Pathan, C.D. Lokhande, App. Surf. Sci., 2005, 245, 328-334, doi: 10.1016/j.apsusc.200410.025

[153] T. Yukawa, K. Kuwabara, K. Koumoto, Thin solid films, 1996, 286, 151-153, doi: 10.1016/S0040-6090(96)08545-8.

[154] M. B. Dergacheva, V. V. Chaikin, Russ. J. Appl. Chem., 2008, 81, 614, doi: 10.1134/S1070427208040083.

[155] N. Kavear, M. Hyland; R. Hill, Turk. J. Phys. 1993, 17, 818. [156] Yu. V. Rud, Semiconductors, 1999, 33, 870, doi: 10.1134/1.1187801.

[157] J. Yang, Z. Jin, Y. Chai, H. Du, T. Liu, Mater.letters, 2008, 62, 4177-4180, doi: 10.1016/j.matlet.2008.05.065.

[158] R.S. Patil, C.D. Lokhande, R.S. Mane, H.M. Pathan, J. OhShim; H. Sung-Hwan, Sci. and Engg. $\quad$ B, 2006, 129, 59-63, doi: 10.1016/j.mseb.2005.12.027.

[159] P. S. Patil, Mater. Chemistry and Physics, 1999, 59, $185-$ 198, doi: 10.1016/S0254-0584(99)00049-8.

[160] T. Tomoaki, S. Inoue; T. Kariya, S. Shirakata, Sol. Energy Mater. Sol. Cells, 2007, 91, $1152-1159$, doi: 10.1016/j.solmat.2006.06.063.

[161] S. Shirakata, M. Tomonori, K. Tetsuya, I. Shigehiro, Jpn J. Appl. Phys., 1996, 35, 191-199, doi: 10.1143/JJAP.35.191.

[162] Y. D. Tembhurkar, J.P. Hirde, Thin solid films, 1992, 215, 65-70, doi: 10.1016/0040-6090(92)90702-D.
[163] R.A. Michelson, W. S. Chen; in proceeding of the 16th IEEE on specialist Conference, San Diago, 1982,781.

[164] Jang Bo Shim, Chang Gyoun Kim, Dong Ju Jeon, Taek-Mo Chung, Ki-Seok An, Sun Suk Lee, Jong Sun Lim, Seok Jong Jeong, Bo Keun Park, Young Kuk Lee, J.l of Phy.and Chem. of Solids, 2013, 74, 867-871, doi: 10.1016/j.jpcs.2013.02.002.

[165] S. Sugan, K. Baskar, R. Dhanasekaran, Curr. Appl. Phys., 2014, 14, 1416e1420, doi: 10.1016/j.cap.2014.08.011.

[166] Kegao Liu, Hui Liu, Yong Xu, Li Zhang J.Appl. Biomater. Funct. Mater., 2016, 14, S77-S79, doi: 10.5301/jabfm.5000305

[167] J. Ramkumar, S. Ananthakumar, S. Moorthy Babu Solar Energy, 2014, 106, 177-183, doi: 10.1016/j.solener.2014.04.010. [168] Jeng-Shin Ma, Subrata Das, Che-Yuan Yang, Fuh-Shan Chen, Chung-Hsin Lu, Ceram. Internat., 2014, 40, 7555-7560, doi: 10.1016/j.ceramint.2013.12.106

[169] A. A. Akl, H.H. Afify, Mater. Resear. Bulle.,2008, 43, 15391548, doi: 10.1016/j.materresbull.2007.06.018.

[170] A. Zouaoui, M. Lachab, M. L. Hidalgo, A. Chaffa, C. Llinares, N. Kesri, Thin Solid Films,1999, 339, 10, doi; 10.1016/S0040-6090(98)00893-1.

[171] J. R. Tuttle, D. S. Albin, R. Noufi, Solar Cells, 1991, 30, 21, doi: 10.1016/0379-6787(91)90034-M.

[172] K. Bindu, C. Sudha kartha, K. Vijayakumar; T. Abe, Y. Kashiwaba, Sol. Energy Mater. Sol. Cells,2003, 79, 67-79, doi: 10.1016/S0927-0248(02)00367-7.

[173] J. Yang, Z. Jin, C. Li, W. Wang, Y. Chai, Electrochem. Commun., 2009, 11, 711-714, doi: 10.1016/j.elecom.2008.12.062. [174] T. Yamaguchi, M. Naka, S. Nllyama, T. Imanishi, J.Phys. Chem. Solids, 2005, 66, 2000, doi: 10.1016/j.jpcs.2005.09.073.

[175] C. Sene, M. Calixto; K. Dobson, R. Birkmire, Thin Solid Films, 2008, 516, 2188-2194, doi: 10.1016/j.tsf.2007.07.142

[176] M. Kemell, M. Ritala, M. Leskela, Crit. Rev. Solid State, 30 (2005) 1, doi: 10.1080/10408430590918341.

[177] W. E. Devaney, R.A. Michelson, W. S. Chen, Proc. 18th IEEE Conf. Photovolt. Specialists., New York, 1985, 1733.

[178] C. H. Fischer, H. J. Muffler M. Bar T. Kropp, A. Schonmann S. Fiechter, G. Barbar, M. C. Lux-Steiner, J. Phys. Chem. B, 2003, 107, 7516-7521, doi: 10.1021/jp034911h [179] D. Pertain, Solar cells and their application, Wiley, 1995, 600 .

[180] G. Hodes, G. Alexandrowitz, D. Cahen, Tech. Rep. Nov. 1984 to Feb. 1985., Proj. No. IL-5-041-32-1 to SERI (USA) [181] S. Shirakata, M. Tomonori, K. Tetsuya, I. Shigehiro, Jpn J. Appl. Phys., 1996, 35, 191-199, doi: 10.1143/JJAP.35.191.

[182] S. Dennison, J. Mater. Chem.,1994,4,41, doi: 10.1039/JM9940400041

[183] P. Kistiah, M. Satyanarayana, Journal of material science Letters, 1984, 3, 767-772, doi: /10.1007/BF00727968. 
[184] V. Pillai, K. P. Vijayakumar, Sol. Energy Mater. Sol. Cells, 1984, 51, 47-54, doi: 10.1016/S0927-0248(97)00207-9.

[185] O. Volobujeva, J. Kois, K. Traksmaa, K. Muska V. Bereznev, M. Grossberg, E. Mellikov, Thin solid films, 2008, 516, 7105-7109, doi: 10.1016/j.tsf.2007.12.024.

[186] J. Kois S. Bereznev O. Volobujeva, E. Mellikov, Thin solid films, 2007, 515, 5871-5875, doi: 10.1016/j.tsf.2006.12.157

[187] B. Canava, J. F. Guillemoles, J. Vigneron D. Lincot A. Etcheberry, J. phys. Chem. Solids,2003, 64,1791, doi: 10.1016/S0022-3697(03)00201-4.

[188] K. Muller, R. Scheer, Y. Burkov, D. Schemeiber, Thin solid films, 2004, 451, 120, doi: 10.1016/j.tsf.2003.11.001.

[189] S. Percharmant, J. F. Guillemoles, J. Vedel, D. Lincot, 11 th Int. Conf. on Ternary and Multinary Compounds ICTMC-11 Salford, 1997, 719.

[190] T. Delsol, M. C. Simmonds, I. M. Dharmadasa, Sol. Energy Mater. Sol. Cells, 2003, 77, 331, doi: 10.1016/S09270248(02)00352-5.

[191] M.E. Calixto, P.J. Sebastian, Sol. Energy Mater. Sol. Cells, 2000, 70, 335-345, doi: 10.1016/S0927-0248(00)00053-2.

[192] S. Bereznev, J. Kois, E. Mellikov, A. Opik, Baltic polymer Symposium, 2001,148-154.

[193] A. Goetzberger, J. Luther, and G. Willeke, Sol. Energy Mater. Sol. Cells,2002,74,1.

[194] R. W. Birkmire, Sol. Energy Mater. Sol. Cells, 2001, 65, 17, doi: 10.1016/S0927-0248(00)00073-8.

[195] A. S. Bahaj, Energy, 2002, 27, 97, doi: 10.1016/S09601481(01)00162-8.

[196] A. Shah, P. Torres, R. Tscharner, N. Wyrsch, and H. Keppner, Science, 1996, 285, 692, 10.1126/science.285.5428.692.

[197] T. Kojima, T. Koyanagi, K. Nakamura, T. Yanagisawa, K. Takahisa, M. Nishitani, and T. Wada, Sol. Energy Mater.Sol. Cells, 1998, 50, 87, doi: 10.1016/S0927-0248(97)00126-8.

[198] M. A. Green, K. Emery, D. L. King, S. Igari, and W. Warta, Prog.Photovolt. Res. Appl., 2003, 11, 347, doi: 10.1002/pip.499 [199] K. W. Mitchell, C. Eberspacher, J. Ermer, K. Pauls, D. Pier, and D. Tanner, Proceedings of the Photovoltaic Science and Engineering Conference, Sydney, Australia, February, 1989, 14 17.

[200] K. W. Mitchell, C. Eberspacher, J. H. Ermer, K. L. Pauls, and D. N. CuInSe $\mathrm{C}_{2}$ cells and modules, Pier, IEEE Trans. Electron Devices, 1990, 37, 410.

[201] D. E. Carlson, The Physics of Hydrogenated Amorphous Silicon I, Structure, Preparation, and Devices, edited by D. Joannopoulos and J. Lucovsky, Springer, Berlin, 1984, 203-241. [202] C. Eberspacher, J. Ermer, C. Frederic, C. Jensen, R. Gay, D. Pier, D. Willett, and F. Farg, in Proceedings of the 10th EC Photovoltaic Solar Energy Conference, 1991.
[203] T. L. Chu, performance measured at the Solar Energy Research Institute.

[204] S. P. Albright, J. F. Jordan, B. Ackerman, and R. R. Chamberlin, Sol.Cells, 1989, 27, 77, doi; 10.1016/03796787(89)90018-5.

[205] K. W. Mitchell and H. I. Liu, Proceedings of the 20th Institute of Electrical and Electronics Engineers Photovoltaic Specialists Conference, Las Vegas, September 26-30, 1988 (Institute of Electrical and Electronics Engineen, New York, 1988 , 1461.

[206] M. Roy, S. Damaskinos, and J. E. Phillips, Proceedings of the 20th Institute of Electrical and Electronics Engineers Photovohaic SpeciaiistsConference, Las Vegas, September 26-30, 1988, Institute of Electrical and Electronics Engineers, New York, 1988,1618 .

[207] M. Roy, Ph.D. dissertation, University of Delaware, 1988. [208] P. Garg, A. Garg, A. C. Rastogi, and J. C. Garg, J. Phys. D. Appl. Phys. 1991, 24, 2026, doi 10.1088/0022-3727/24/11/018.

[209] S. N. Sahu, R.D. L. Kristensen, and D. Haneman, Sol. Energy Mater, 1989, 18, 385, doi: 10.1016/01651633(89)90063-4.

[210] C. X. Qiu, and I. Shih, Can. J. Phys. 1987, 65, 1011, doi: $10.1139 / \mathrm{p} 87-163$.

[211] L. Stolt, J. Hedstr“om, J. Kessler, M. Ruckh, K.-O. Velthaus, and H.-W. Schock, Appl. Phys. Lett., 1993, 62, 597, doi: 10.1063/1.108867.

[212] V. K. Kapur, B. M. Ba,Sol, and E. S. Tseng, Solar cells, Sol. Cells, 1987, 21, 65, doi: 10.1016/0379-6787(87)90105-0.

[213] S. N. Qiu, L. Li, C. X. Qiu, I. Shih, and C. H. Champness, Sol. Energy Mater. Sol. Cells, 1995, 37, 389, doi: 10.1016/09270248(95)00033-X.

[214] J. Hedstr”om, H. Ohlsen, M. Bodegard, A. Kylner, L. Stolt, D. Hariskos, M. Ruckh, and H.-W. Schock, Conf. Rec. 23rd IEEE Photovolt. Spec. Conf. IEEE, Piscataway, N.J., 364, 1993.

[215] A. Rockett and R. W. Birkmire, J. Appl. Phys., 1991, 70, R81, doi: 10.1063/1.349175.

[216] D. Schmid, M. Ruckh, F. Grunwald, and H. W. Schock, J. Appl. Phys., 1993 73, 2902, doi: 10.1063/1.353020.

[217] Y. Sudo, S. Endo, and T. Jpn. J. Appl. Phys.,1993, 32, 1562, doi: 10.1143/JJAP.32.1562.

[218] R.W. Birkmire and E. Eser, Annu. Rev. Mater. Sci.1997, 27, 625, doi: 10.1146/annurev.matsci.27.1.625.

[219] H.-W. Schock and R. Noufi, Res. Appl. 2000, 8,151, doi: 10.1002/(SICI)1099159X(200001/02)8:1<151::AID-

PIP302>3.0.CO;2-Q.

[220] C. J. Brabec, N. S. Sariciftci, J. C. Hummelen, Adv. Funct. Mater, $\quad 2001, \quad 11, \quad 1-15, \quad$ doi: 1002/16163028(200102)11:1<15::AID-ADFM15>3.0.CO;2-A. 
[221] G. Yu, A. J. Heeger, J. Appl. physics., 1995, 78, 4510, doi: 10.1063/1.359792.

[222] J. J. M. Halls, R. H. Friend, Synth. Met., 1997, 85, 1307, doi: 10.1016/S0379-6779(97)80252-4.

[223] P. J. Sebastian, S. A. Gamboa, M. E. Calixto, H. NguyenCong, P. Chartuer, R. Perez, Semicond. Sci. Echnol.,1998, 13, 1459, doi: 10.1088/0268-1242/13/12/023.

[224] C.D. Lokhande, J. Electrochem. Soc., 1987, 134, 1727, doi: 10.1149/1.2100745.

[225] T. J. Coutts, K.A. Emery, S. Ward, Prog. Photovolt. Res. Appl., 2002, 10, 195, doi: 10.1002/pip.491.

[226] X. Wu, J. Zhou, A. Duda, J.C. Keane, T.A. Gessert, Y. Yan, R. Nou, Mater. Res. Symp. Proc., 2005, 865, F11.4.1.

[227] J. Piekoszewski; J. J Loferski.; R. Beaulieu; J. Beall; R. Roessler; J. Shewchun, Sol. Energy Mater., 1980, 2, 363, doi: 10.1016/0165-1633(80)90012-X.

[228] R. Durny, A. E. Hill, R. D. Tomlinson, Thin Solid Films., 1980, 69, L11, doi: 10.1016/0040-6090(80)90044-9

[229] J. Burdick, T. Glatfelter, Solar Cells, 1986, 18,301-314, doi: 10.1016/0379-6787(86)90129-8.

\section{Author information}

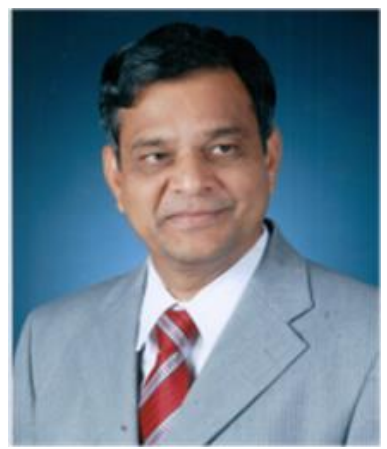

Prof $\boldsymbol{C} D$ Lokhande is presently working as a Dean and Research Director at D Y Patil Education Society (Deemed to be University), Kolhapur, India.He has been working on several areas of thin film technology, ranging from chemical synthesis of thin films to their applications in solar cells, gas sensors, and supercapacitors.

Moreover, he made a great contribution in designing several prototype devices such as supercapacitors and heterojunction-based room temperature gas sensors. He received his Ph.D. from Shivaji University, Kolhapur in 1984, without viva voce examination as his thesis was adjudged as "Excellent." Later, in 1987, he joined as assistant professor in Physics and became professor and Head at Shivaji University, Kolhapur, immediately after accomplishing his first postdoctoral stay at the Weizmann Institute of Science, Israel. He has won many awards and received many honors. He was appointed as Fellow of Institute of Physics, London, in 1990; was visiting scientist in the Indo-Polish CEP scheme in 1991; was INSA Visiting Fellow in 1993; is the first recipient from Shivaji University of the prestigious Alexander von Humboldt Fellowship, Germany, in 1996 and Brain Pool fellowship of South Korea in 2003; was participant in Noble Laureates Meeting, Lindau, Germany in 2001; was visiting professor at Hanyang University, South Korea in 2006; was awarded a RajyaShishakPurshakar, Government of
Maharashtra State in 2009, and Best Teacher Award from Shivaji University in 2010. He is presently an editorial board member of "Electrochemical Energy Technology," De Gruyter; the fellow, Maharashtra Academy of Sciences from 2012; an expert member, distinguished visiting professor in polymer chemistry, Institute of Chemical Technology, Mumbai from 2012. He is the author of more than 600 papers in international journals with " $h$ " index 90 and more than 29,000 citations, edited 11 books, filed more than 45 patents, and directed more than 60 Ph.D. theses. Recently, he has been listed at first position in top $2 \%$ scientists in the subject of Applied Physics in India by the Stanford University Survey

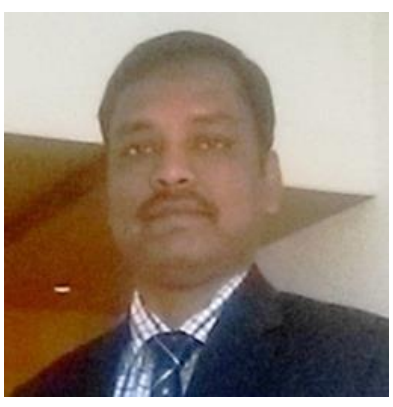

Dr. H. M. Pathan received his Ph.D. in 2003 from Shivaji University, Kolhapur, India. Afterwards, he joined with Prof. O. S. Joo at the Korea Institute of Science and Technology Seoul, South Korea, as a post-doctoral fellow in 2004. Since 2008 he is full Assistant professor in Physics at the department of Physics Savitribai Phule Pune University Maharashtra, India and Visiting Professor Chonbuk National University, Iksan, Republic of Korea, 1-15 May, 2018. His research is focused on material science, energy conversion and storage devices, solar cell and supercapacitors. He is also the Coordinator of the UPE-II for DSSC group. Chief Guest Editor: J. Nanotechnology Special issue Functional Nanomaterials. Guest Editor: J Mater Sci Mater Elect Special issue: Mater. Photovoltaics from Solar Asia 2015. He is Life Member/Member of different institutions/organizations and is lead Guest Editor for Special issues etc. He is the author of more than 100 articles in peer-reviewed international journals and 5 review articles with 2800 citations and the founding Executive Editorial board of ES Energy \& Environment journal.

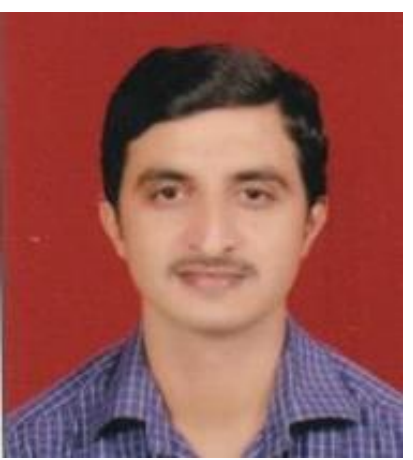

Dr. Balasaheb M. Palve Palve is presently working as an assistant professor at the Department of Physics, S.N. Arts, D.J. M. Commerce, B.N.S. Science College, Sangamner. He received his Ph.D. from the Department of Physics, Savitribai, Phule Pune University, India under the guidance of Dr. H.M. Pathan in 2018. He completed his M.Sc in Material Science from the Department of Physics, Savitribai Phule Pune University, India in 2008. He has been working on thin-film technology and its application in various types of solar cells. He has published 15 research papers in an international and national reputed journal. He is presently working as a reviewer of various journals such as 
Electrochimica Acta, Journal of Material Science, Material Science in semiconductor processing, Material research express, etc. He has participated in various International and National conferences based on material science. He was awarded the Inspiration teacher award from S.N. Arts, D.J.M. Commerce, B.N.S. Science College Sangamner, India in 2018.

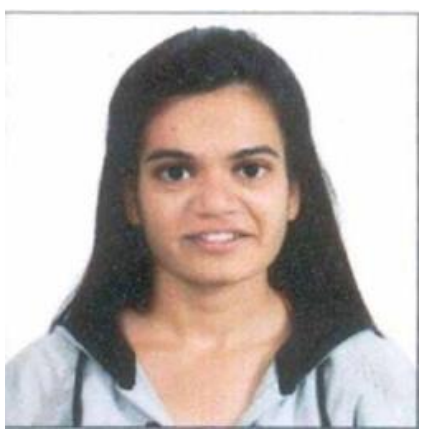

Miss Chaitali Vishwas Jagtap is presently working as Women Scientist under the WOS-A scheme of the Department of Science and Technology, Government of India at Advanced Physics Laboratory, Department of Physics, Savitribai Phule Pune University, Pune under the guidance of Dr. H. M. Pathan. She has more than 15 publications in International journals. She received her M.Sc. degree in 2014 from Fergusson College, Pune, and M.Phil. degree in 2018 from Savitribai Phule Pune University. Her work is focused on Dye Sensitized Solar Cell. She has worked on various synthesis and fabrication of various metal oxides semiconductors such as $\mathrm{TiO}_{2}, \mathrm{ZnO}$, etc.

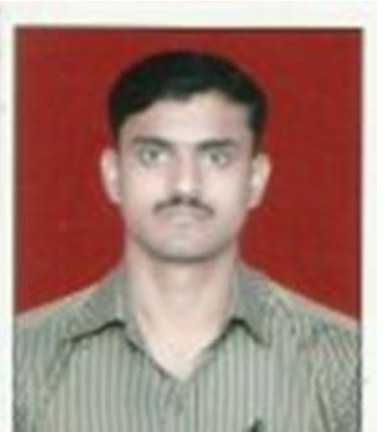

Mr. Vishal Sunil Kadam is presently completing his Ph.D. at the Department of Physics, Savitribai Phule Pune University, Pune under the guidance of Dr. $H$. M. Pathan. His research is focused on the third generation solar cell. He has more than 20 publications in International journals. 5 years of research experience on nanomaterials synthesis and characterization for Sensor and solar cell application from Advanced Physics Laboratory, Department of Physics, Savitribai Phule Pune University, Pune, and Center for Material for Electronics Technology (C-MET), Pune. He has worked on various fabrication of metal oxide photoanodes by spray pyrolysis, chemical bath deposition, SILAR.

Publisher's Note: Engineered Science Publisher remains neutral with regard to jurisdictional claims in published maps and institutional affiliations. 